\title{
A LABOR-INCOME-BASED MEASURE \\ OF THE VALUE OF HUMAN CAPITAL: \\ AN APPLICATION TO THE STATES \\ OF THE UNITED STATES
}

Casey B. Mulligan

Xavier Sala-i-Martin

Working Paper No. 5018

\section{NATIONAL BUREAU OF ECONOMIC RESEARCH 1050 Massachusetts Avenue \\ Cambridge, MA 02138 \\ February 1995}

Our research has benefited from discussions with Robert Barro, Gary Becker, Jess Benhabib, Fischer Black, Tove Edstrand, Jordi Gali, Jim Heckman, Hugo Hopenhayn, Dale Jorgenson, Boyan Jovanovic, Per Krussell, Robert Lucas, Yair Mundlak, Kevin Murphy, Derek Neal, Juanpa Nicolini, Etsuro Shioji, Chris Sims, Anna Sjogren, Nancy Stokey, Petra Todd, Calçotada de Valls, Alwyn Young and participants at seminars at the Universities of Chicago, Pompeu Fabra, IVIE, NYU, CEPR, IMF and NBER. This paper is part of NBER's research program in Growth. Any opinions expressed are those of the authors and not those of the National Bureau of Economic Research.

(C) 1995 by Casey B. Mulligan and Xavier Sala-i-Martin. All rights reserved. Short sections of text, not to exceed two paragraphs, may be quoted without explicit permission provided that full credit, including () notice, is given to the source. 


\title{
A LABOR-INCOME-BASED MEASURE OF THE VALUE OF HUMAN CAPITAL: AN APPLICATION TO THE STATES OF THE UNITED STATES
}

\begin{abstract}
We argue that a sensible measure of the aggregate value of human capital is the ratio of total labor income per capita to the wage of a person with zero years of schooling. The reason for that is that total labor income not only incorporates human capital, but also physical capital: given human capital, regions with higher physical capital will tend to have higher wages for all workers and, therefore, higher labor income. We find that one way to net out the effect of aggregate physical capital on labor income is to divide labor income by the wage of a zeroschooling worker.

For the average U.S. state, our measure suggests that the value of human capital during the 1980s grew at a much larger rate than schooling. The reason has to do with movements in the relative productivities of the different workers: in some sense, some workers and some types of schooling became a lot more relevant in the 1980s and, as a result, measured human capital increased.
\end{abstract}

Casey B. Mulligan

Department of Economics

University of Chicago

1126 East 59th Street

Chicago, IL 60637
Xavier Sala-i-Martin

Department of Economics

Yale University

28 Hillhouse

New Haven, CT 06520

and NBER 


\section{INTRODUCTION}

There is no question that the U.S. labor force has become more "educated" in the past 50 years. Compare, for example, our figures $1 \mathrm{a}$ and 1f. The figures display histograms of educational attainment of the U.S. aged 25-65 civilian labor force for the years 1940 (Figure 1a) and 1990 (Figure 1f). We see that in 1940 a mere 12 percent of the labor force had completed even a year of college. Only 15 percent more had completed high school. By 1990, over half of the labor force had attended some college and another 30 percent had completed high school. Only 16 percent of the labor force did not have a high school diploma.

Can we say that such dramatic changes in the educational attainment of labor force is an important source of economic growth? Well, income and wage rates have grown along with educational attainment over the same period so we could be tempted to say yes. Time spent in school has grown, but so has hours of television viewing. Can we argue that television viewing is responsible for productivity growth?

In defense of the virtues of schooling, it is true that, at a point in time, workers with lots of schooling enjoy higher wage rates than observationally equivalent workers with less schooling. The same cannot be said for television viewing. Thus, one might estimate the productivity value of our country's increased educational attainment by multiplying a cross-sectional estimate of the skill premium (the wage ratio of say, college to high school workers) by the increase in educational attainment. In fact, this will be one of the ways in which we compute human capital in this paper. Although this is an interesting measure, it has drawbacks. First, while those few workers who appear in the right two or three bars of the histogram in figure la may have had more schooling, they may also have differed from the rest of the labor force according to other unobservable characteristics: IQ, family background, and health are some examples. Our schools have been clearly granting diplomas, but have they been granting these other characteristics? In short, schooling may not be related to the same quantity of human capital that it used to. Second, the relevance of what is taught in school may not be constant. For example, there could be an increasing aggregate tendency to study things that are not directly productive (such as 
Egyptology, moral philosophy of XVI century monks, or theoretical time series econometrics). If this were the case, an increase in the number of years of schooling could be consistent with a decline in the actual amount of productive human capital. Similarly, technological changes may render certain types of teachings obsolete. If schools do not adapt to the new technological situation, then schooling may increase but human capital may not. 1

In this paper we consider alternative measures of human capital that are not so quick to IDENTIFY schooling with human capital. In particular, we propose to measure the value of the input human capital as the ratio of the aggregate labor income of an economy to the wage of the uneducated. Our measure clearly overcomes some of the shortcomings of existing measures of human capital (for example, when the quality and the relevance of what is taught increases, the labor income of the educated increases with it so our measure correctly captures this phenomenon).

We should mention at the outset that there are some drawbacks in the way we compute human capital. Two of the most important ones are that wages may change for reasons other than changes in human capital. When this happens, our measure will incorrectly show changes in human capital. A second potential source of problems could be that we assume that the uneducated are perfect substitutes for the rest of the labor force. In the final section we provide some evidence to support this view. But to the extent that this assumption does not hold, our computations will be flawed.

The rest of the paper is organlzed as follows. Section II reviews some standard microeconomic theories of schooling, income and human capital, but pays special attention to those issues which we think are important for measurement. Section III presents our data sources and our different measures of human capital. We compare the various measures for each of the contiguous 48 states in each of the 6 Census years 1940-90. Most of

1 One could give examples of macroeconomic theorles which have "recently" become obsolete. We will not give such examples although, clearly, there must be schools which have not adapted to the new technological environment. 
discussion and analysis considers human capital indices which linearly aggregate varlous types of labor. Section $V$ considers generalizations of our results to nonlinear aggregators.

\section{MICROFOUNDATIONS}

\section{A. AGGREGATE PRODUCTION}

We imagine that output $Q$ at the aggregate level is determined by an aggregate production function that depends on two inputs: the total human capital and total nonhuman capital $K$ in the economy.

$$
Q_{1}(t)=F\left(v_{1}(t) K_{i}(t), u_{i}(t) H_{i}(t)\right)
$$

1 indexes a state while $t$ is a time index. $H_{1}(t)$ is the total stock of human capital ${ }^{2}$ in the state, and $u_{i t}$ is the participation rate (all persons might not be involved in market production) and $v_{1}(t)$ is the fraction of nonhuman capital, $K_{i}(t)$, devoted to productive activities (as opposed, for example, to education activities).

Human capital is related to the aggregate stock of productive human bodies available in an economy. That is, the concept of human capital is related to the labor force. In principle, human capital includes all productive aspects of the human bodies in the state; education, on the job training, physical and mental fitness, and the quality of matches between workers and firms are some examples. Since the population of an economy is heterogeneous - some citizens have a lot of skills while others have little or none - different people contribute to production in different degrees. We want our measure of human capital to capture this phenomenon so we cannot simply add all the bodies in the economy to compute human capital: we need

2

Note that output should depend on the flow of services rather than the stock of human capital. The customary assumption is that the flow of services variable is proportional to the stock variable. 
to give a larger welght to those people who are more productive. In some sense, we want to do with labor what empirical economists like Jorgenson and others have done with physical capital: add the number of machines but giving each unit a weight which is proportional to its productivity. In this spirit, we define aggregate human capital in an economy as the quality-adjusted sum of the labor of all its citizens:

$$
H_{1}(t)=\int_{0}^{\infty} \theta_{1}(t, s) N_{1}(t, s) d s .
$$

where $N_{1}(t, s)$ denotes the number of people in economy 1 at date $t$ with $s$ years of schooling. Note that each type of worker contributes to our definition of aggregate human capital according to his efficiency parameter $\theta_{1}(t, s)$. $^{3}$

In order to clarify the concept of human capital, let us suppose that we choose a worker with $s$ years of schooling to be the numeralre. ${ }^{4}$ We will say that the stock of human capital in state 1 is $H_{1}(t)$ if we can say that, instead of the actual distribution of people and skills, economy 1 had $H_{1}(t)$ units of workers with s years of schooling, then it would produce the same amount of output (holding constant the aggregate stock of physical capital and the level of technology). Note that the notion of human capital is independent of the exact functional form of the aggregator in (2).

The specification in (2) assumes that workers of different schooling levels are perfectly substitutable. For example, $\theta_{1}(t, 16)$ high school graduates (who generally have 12 years of schooling) can be substituted for $\theta_{1}(t, 12)$ college graduates (who generally have 16 years of schooling) without

3 We integrate over the level of schooling of the population. More generally we would like to integrate over other characteristics also. We will do so when we perform our empirical implementation. However, we will not show the algebra here in order to simplify the exposition.

4 In principle, we could choose any type of worker to be the numeraire. In the next section we will argue, however, that the only sensible numeraire is the person with zero years of schooling. 
changing aggregate production. We will argue in Section $V$, however, that our preferred measure of human capital is consistent with finite elasticity of substitution across different types of workers.

We belleve that a person's human capltal is related to his schooling, but have no presumptions, a priori, about the precise relationship between one's schooling and one's human capital. The relationship might be linear or nonlinear and need not even be increasing. In other words, when $\theta_{i}(t, s)$ denotes the mapping from a person's years of schooling (s) to his human capital, we make no assumptions about the functional form or even the sign of the derivative of this function.

Divide the aggregate stock of human capital by the stock of workers to get the avarage stock of human capital in economy 1 at $t$ ime $t$ as

$$
h_{i}(t)=\int_{0}^{\infty} \theta_{1}(t, s) \eta_{1}(t, s) d s,
$$

where $\eta_{1}(t, s)=N_{1}(t, s) / N_{1}(t)$ is the share of state I's population with $s$ years of schooling at time $t$ and $h_{1}(t)=H_{1}(t) / N_{1}(t)$ is the stock of human capital per person. An important question is how to compute the efficiency parameters which will be used as weights to add people up. In particular, we want to know whether we should allow these efficiency parameters to vary across states and over time. We also want to get some guidance as to which category of workers (if any) is an appropriate numeraire.

II.B. EFFICIENCY PARAMETERS AND CHOICE OF A NUMERAIRE:

GUIDANCE FROM A MODEL OF INDIVIDUAL HUMAN CAPITAL ACCUMULATION

The goal of this subsection is to use economic theory to guide us in the measurement of the efficlency parameters $\theta_{1}(t, s)$. There are two questions that we would like the theoretical analysis to answer. First, should the efficlency parameter for a given level of schooling vary over space and time, over time only $\left(\theta_{1}(t, s)=\theta(t, s)\right)$, or not at all $\left(\theta_{1}(t, s)=\theta(s)\right)$ ? Second, how might the efficiency parameters $\theta_{1}(t, s)$ be related to years of schooling $s$ ? To answer these questions, we will consider a parameterized model of individual human capital accumulation, but the basic insights will be robust 
to changes in the functional form. The more important functional form assumptions are the aggregate ones in the previous section.

Let $h_{j 1}(t)$ be the skill level or stock of human capital of individual $\mathrm{J}$ in state 1 at time $t$. We assume that an individual can increase his skill by combining some aggregate inputs with his own time and skill. The aggregate variables could be the stock of physical capital $\hat{k}_{1}^{\mathbf{e}}(t)$ devoted to education (related to the physical facilities in schools and other learning centers) and the stock of human capital, $\hat{h}_{i}^{e}(t)$, devoted to education in a particular state (the corresponding human capital would refer to skills and the amount of teachers and other educators). The fractions of the economy-wide stocks of human and physical capital devoted to education may vary across regions and over time. The level of technology of education may also vary across regions. 5

Let $\hat{y}_{1}(t)$ summarize the effects of a region's aggregate variables on individual's human capital accumulation. ${ }^{6}$ An example of a $\hat{y}_{1}(t)$ function would be the Cobb Douglas $\hat{y}_{1}(t)=\phi_{1} \hat{k}_{1}^{e}(t)^{\alpha} \hat{h}_{1}^{e}(t)^{1-\alpha}$, where $\phi_{1}$ is the level

5 We are implicitly assuming that economies are closed in the sense that kids must go to school in their own economies. In the real world, this assumption will not be strictly correct since some students will find it optimal to study out of state. Furthermore, workers may migrate across economies once their schooling has been completed. Hence at a point in time, the labor force of a particular state will have had schooling in different states.

We make the close economy assumption just to bring in the main points clearly. In practice, we will not impose that the productivity parameters of the different levels of schooling follow the equations derived from the theory. We will estimate them with no restrictions and without relating them to the amount of aggregate resources devoted to schooling in a particular state. In particular, we will not require that the levels of productivity to be different across economies, and we will not even impose them to be increasing in schooling. Hence, to the extent that these issues are important, they will show up in the data, although not in our theoretical discussion.

6 We suppress the details of the schooling market. One might imagine that students rent the services of teachers and various capital goods (ie, pay tuition). 
of technology (for education) in state 1. As a particular example, we may want to think of human capital being produced with human capital only (as in Uzawa (1965) and Lucas (1988), $\hat{y}_{1}(t)=\phi_{1} \hat{h}_{1}^{e}(t)$ ) We imagine that, in order to increase one's human capital, an individual combines his own human capital with the aggregate stocks avallable in his region according to

$$
\dot{h}_{j 1}(t)=\hat{y}_{i}(t)^{1-\psi}\left(u_{j 1}(t) h_{j 1}(t)\right)^{\psi}
$$

with $0 \leq \psi \leq 1$, where $u_{j}$ is the fraction of his own human capital the individual devotes to education. Equation (4) implies that the longer the time spent in school, the more skill one individual will accumulate. It also implies that spending the same amount of time in school in regions with a lot of physical and human capital devoted to education ylelds a bigger increase in the individual level of skill. Finally, the level increase in the amount of skill is larger for people with high skill. Because $\psi$ is less than one, however, the learning process is subject to diminishing returns to skills. 7

To simplify notation, we imagine that the aggregate stock $\hat{y}_{1}(t)$ grows at a constant rate $\gamma_{1}$. This would be the case if, for example, state 1 was in the steady state of an aggregative growth model. ${ }^{8}$ We also assume that students can only use their human capital in school (that is, they are not allowed to use their human capital to productive activities until they get out of school) so $u_{j 1}=1$ for all $t$. Different students, however, will spend different number of years in school and, as a result, will end up with different skill levels. Compute the level of skill of a person who went to school between times $v$ and $v+s$ by integrating (4) between $v$ and $v+s$ :

$$
h_{j 1}(v, s)=\left[h_{j 1}(v, 0)^{1-\psi}+(1-\psi) \hat{y}_{1}(v)\left(e^{\gamma_{1} s}-1\right)\right]^{1 /(1-\psi)} \text {, }
$$

7 The Cobb-Douglas formulation is not critical. The closed-form solutions that it permits, however, facilitates the exposition.

8 As 1 t will be apparent from the analysis, this assumption is not crucial for any of the results we will derive in this section. 
where $h_{j i}(v, 0)$ is the stock of human capital the student had at the moment when he had zero years of schooling. That is, the stock of human capital of a student 1 who started school at time $v$ in region 1 and who studied for $s$ years is a function of the sum of his initial stock human capital, $h_{j i}(v, 0)$, plus the term $\hat{y}_{1}(v)\left(e^{\gamma}-1\right)$. This second term, which reflects the increase in the stock of the student's human capital over the period of length $s$, is the product of the quality of the teachers and amount of education facilities available at the beginning of his student career, $\hat{y}_{1}(v)$, times an exponential term which is increasing in the number of years of schooling. In other words, a given amount of schooling represents different amounts of human capital in different places and different times because the quality of schooling is different. Finally, note that when $s=0$, the second term is zero so the level of skill is $h_{j i}(v, 0)$.

THE INITIAL LEVEL OF SKILL

An important question is what is the initial stock of human capital, $h_{j i}(v, 0)$. We assume that the initial stock is the same at all points in time and in all places

$$
h_{j 1}(v, 0)=h(0)
$$

for all v, 1 and $j$. In other words, a zero-schooling person is the same, always and everywhere. This assumption does not imply that zero-schooling people will earn the same income always and everywhere. Their productivity (and wage) will differ across economies because the aggregate stocks of physical, human capital, and other inputs will differ across economies. That is, individual productivity not only depends on the individual stock of skill, but also on the available stocks of the other inputs as well as the level of technology.

The main reason for using assumption (6) is that we need a numeraire. We want to express the human capital index in a unit which is homogeneous across space and time. Equation (5) suggests that having any amount of schooling will tend to introduce interregional and intertemporal differences 
in the level of skill, simply because the resources devoted to education and the level of human capital of the teachers will differ across economies. Hence, while the analysis above admits assumption (6), it does not reasonably admit any other normalization: people with any positive amount of schooling will necessarlly be different and, therefore, cannot be used as numeraire. 9

THEORETICAL MEASURES OF AGGREGATE HUMAN CAPITAL

One way to compute (theoretically) an aggregate stock of human capital is to sum the level of skill of every individual of the economy. We do so in two steps. First, we compute the stock of human capital of all workers with $s$ years of schooling by integrating (5) over all $v$ for people who are alive today. Imagine that people with s years of schooling live for $T_{s}$ years. The oldest people alive today were born in period $t-T_{s}$, but they did not start working until $s$ years later (because they were in school). Assuming that there is one individual of this type born and starting school at each instant $v$, the skill of the average person with $s$ years of schooling $s$ is given by

$$
h_{i}(t, s)=\int_{t-T_{s}+s}^{t} h_{j i}(v, s) d v,
$$

with $\partial h / \partial s>0$ and $h_{i}(t, 0)=h(0)$ for all $t$ and $i$. Note that the average

9 One might argue that the process of education and human capital accumulation starts before schooling. Kids in daily contact with smart parents and other smart people might tend to have more skills than kids whose parents have a low level of education. This intergenerational transmission of human capital would then make the initial stock of human capital, $h_{j i}(v, 0)$, a function of the aggregate resources available in state $i$ at time $t$.

Another problem is related to the question of why some people have no schooling. The people who have chosen to have no education are, in some sense, 'strange', at least if we talk about the second half of the XX century in the United States. One could reasonably argue that there is little reason for assuming that these strange people are the same in all places and at all points in time. 
level of skill of the people with $s$ years of schooling depends on $i$ and $t$ because the stock of human and physical capital devoted to school in region 1 at the time when the people alive at time $t$ went to school might be different. We also note that the average skill level, $h_{1}(t, s)$, depends on something that looks like a demographic variable, $T_{s}$. This is the length of economics life of people with $s$ years of schooling. This length of life may vary over time, across states or across $s$ (because, for example, more educated people tend to retire at different age).

The second step to compute the aggregate stock of human capital per worker is to add up the people in each category, using (7) as the weights:

$$
h_{1}(t)=\int_{0}^{\infty} h_{1}(t, s) \eta_{1}(t, s) d s .
$$

Note the equation (8) is identical to (3) if the efficiency parameters are defined are given by the average skill levels, $\theta_{i}(t, s)=h_{1}(t, s)$. If we use the normalization $h(t, 0)=1$, then the average stock of human capital in (8) reports the amount of zero-schooling-worker equivalents available in economy $i$ at time $t$.

The main lessons we want to take from this section are two: First, if there is a sensible numeraire, then it has to be the zero-schooling worker. The reason is that any positive amount of schooling will imply different productivities in different economies and in different time periods. Hence, it is only normal that people with positive schooling are different. If we can assume that one type of worker is the same in all economies, it has to be the one who has not been exposed to these economy-wide influences: the worker with no schooling. It follows that the only reasonable numeraire is the zero schooling worker.

The second main lesson is that, even when human capital is homogeneous, the efficiency parameters $\theta_{i}(t, s)$ - which relate years of schooling to productivity - should be allowed to change across regions and over time because skill in different regions has been accumulated under different aggregate circumstances (different amount of skills of teachers, different amounts of physical facilities devoted to schooling and so on). The theoretical analysis suggests that these weights should be increasing in the 
amount of schooling and the amount of aggregate stocks devoted to education.

There is some evidence that "schooling quality" affects the relationship between an individual's years of schooling and his productivity. Card and Krueger (1992) compare wage-schooling profiles across states and notice that workers who studied in higher income states or in states with more expenditures on education enjoy a higher wage premium over less educated, but otherwise similarly situated, workers.

of course, differences in schooling quality (in the sense that we have defined it in this subsection) are not the only reason the wage-schooling relationship might vary across states or over time. We might imagine that the relevance of various levels and types of schooling depends on time and location. Or, unlike our aggregate specification (2), workers of various skills may not be perfect substitutes; the marginal rate of transformation between any two skill groups may depend on the relative quantities of the two types of workers in the economy.

Although this was not directly incorporated in the theoretical reasoning of the preceding section, a related reason for allowing the relative weights to vary over time and across regions is that the relevance of what is taught in school also differs across regions and over time. This relevance may change due to technological shocks which render certain types of education less useful in a productive sense.

In the current paper, we do not attempt to separately attribute changes across states and over time in the wage-schooling relationship to the three aforementioned sources: schooling quality, productivity shocks, and relative supply shocks. Given that workers with no skill are the numeraire, it is not clear that a complete decomposition is necessary. For example, a technology shock that changed the productivity (and therefore wages) of college graduates relative to no-skill workers should be reflected in our human capital index. However, a change in the relative supplies of workers that leaves output constant may lead to a change in the relative wages (if workers of various types are not perfect substitutes as we assume in equation (2)) but should not be reflected in our human capital index. A human capital index that allows for the possibility that the relative supplies of worker types are changing seems like a natural extension to the indices considered here. Section VI asks whether or not our preferred measure of human capital, 
while apparently "linear," is robust to relaxation of the perfect substitutability assumption.

\section{II.C. A LABOR-INCOME-BASED MEASURE OF HUMAN CAPITAL (LIHK).}

Under the assumption that a worker's marginal product equals his wage, the wage rate of a person with $s$ years of schooling is given by

$$
w_{i}(t, s)=\partial Q_{i}(t) / \partial N_{i}(t, s)=\left(\partial F\left(K_{i}, H_{i}\right) / \partial H_{i}\right) \partial H_{i} / \partial N_{i}(t, 0)=F_{H}^{*} \theta_{i}(t, s)
$$

Similarly, the wage rate of a person with zero schooling is given by

$$
w_{1}(t, 0)=F_{H}^{*} h(0) \equiv F_{H} \text {, }
$$

where the normalization $\theta(0) \equiv 1$ has been used. It is clear from (7) and (10) that the average stocks of human capital can be inferred from the wage ratios

$$
\theta_{1}(t, s)=w_{1}(t, s) / w_{i}(t, 0)
$$

The intuition for this result is that the wage rate of a person of any skill has two components. One of them depends on the individual skill. The other component depends on the aggregate stocks. For a given skill, a larger amount of physical capital increases one's productivity because of the complementarity between physical and human capital. Similarly, a larger amount of aggregate human capital decreases it because of diminishing returns to aggregate human capital. In order to identify the skill component, we need to net out the aggregate component. We can do so by dividing by the wage of a person with no skill, $w_{1}(t, 0)$.

By plugging (11) in (8) we get that the average stock of human capital can be measured as

$$
h_{1}(t)=\left[\int_{0}^{\infty} w_{1}(t, s) \eta_{1}(t, s) d s\right] / w_{1}(t, 0),
$$

where, again, $\eta_{i}(t, s)$ is the fraction of people in state 1 with $s$ years of 
schooling at time $t$. We note that the expression inside the square brackets is the sum of all wages in the economy divided by the number of people. In other words, abstracting from differences in the participation rates across schooling groups, the bracketed term is the average labor income of state 1 .

This analysis suggests a simple measure of the aggregate stock of human capital: Compute the average labor income of state $i$ (that is, total labor income per worker), and divide it by the wage of the zero-schooling workers in that state. This is what we will call labor-incone-based human capital (LIHK) throughout the rest of the paper. Aggregate labor income is usually reported in the national accounts. We just need to compute the wage rate of an unskilled person. We will discuss how we do so in section III. 10

\section{II.D. ALTERNATIVE MEASURES OF HUMAN CAPITAL.}

Alternative ways to compute human capital have been proposed in the iiterature. Here we discuss the theoretical differences. In Section III we compute such measures in order to compare them with our labor-income-based human capital.

\section{VARIABLE WEIGHTS}

Our labor-income-based measure of human capital can be thought of as one

10 We should note at this point that, even though we have been emphasizing schooling in our theoretical analysis, the measure of human capital we just proposed includes all productive aspects of human bodles, as long as those aspects are incorporated in the workers' wages. For example, the development 11 terature has emphasized nutrition and health as an important aspect of human capital. Other people have argued that the efficiency of job matching or the amount of on-the-job training or job experience contribute to human capital. To the extent that these characteristics are incorporated in wages, our labor-income-based measure of human capital will capture them (our estimates of $w(0)$ will correspond to workers with no schooling and no experience so anything which affects the general work force but not the average zero-schooling, zero-experience worker will be reflected in our measure of human capital). Finally, LIHK incorporates the notion of relevance of schooling in that, if one has a lot of schooling but learn irrelevant things (irrelevant from a productive point of view, of course), then one's wage is low and our measured LIHK is also low, even though schooling may be high. 
that allows relative efficiencles to vary across time and location. If one thought that the crosi-state differences in skill premia were not do to schooling quality differences or to technological differences, but due to differences in relative supplies, then an alternative is to restrict the weights to be the same across regions, but allow them to vary over time

$$
h_{1}(t)=\int_{0}^{\infty} \theta(t, s) \eta_{1}(t, s) d s,
$$

where $\theta(t, s)$ is independent of 1 . Our analysis suggests that this measure could be appropriate, for example, If the aggregate variables that matter for individual human capital accumulation are nation-wide.

In practice, to compute human capital using (14) we would multiply the fraction of workers in each education category in each state by a nationwide productivity parameter $\theta_{u s}(t, s)$. This nationwide productivity parameters can be computed using relative wages:

$$
\theta(t, s)=w(t, s) / w(t, 0) .
$$

In other words, the average U.S. worker with $s$ years of schooling at time $t$ will be assumed to be $\theta(t, s)$ times more productive than a worker with zero years of schooling because his wage is $w(t, s) / w(t, 0)$ times larger. These weights would be computed at each date.

Note that another difference between the flexible weight measure and LIHK is that the flexible weight forces all workers within the same education category to have the same welght (or productivity) in the total account of human capital. Our measure, on the other hand, gives each person, a weight which is proportional to his own wage.

\section{FIXED WEIGHTS}

The third measure would restrict the efficiency weights to be the same over time as well as across states. The average capital stock would be computed by a weighted average of different educational attainments, the weights being restricted to be the same over time and across states: 


$$
h_{1}(t)=\int_{0}^{\infty} \theta(s) \eta_{1}(t, s) d s,
$$

where the weights $\theta(s)$ are independent of $i$ and $t$. In practice we can compute $\theta(s)$ by dividing the wage of a person with $s$ years of schooling by the wage of the no-schooling worker,

$$
\theta(s)=w(s) / w(0) .
$$

AVERAGE YEARS OF SCHOOLING

The most popular measure of human capital is the average years of schooling. In an international context, for example, this measure has been used by Kyriacou (1991) as well as Barro and Lee (1993). Average years of schooling is computed by adding the product of the number of years of schooling times the number of people in each schooling category across schooling categories:

$$
h_{1}(t)=\int_{0}^{\infty} s n_{1}(t, s) d s .
$$

Note that (16) uses a fixed weight over time and across regions so it is a particular case of (15). Instead of being based on market wages, the fixed weights in (16) are the number of years of schooling. In other words, this measure assumes that, always and everywhere, a person with 16 years of school is 16 times more productive as a person with one year of school (even if his wage is only three times larger). 
II I. MEASUREMENT AND RESULTS.

III.A. SAMPLE SELECTION AND SOME BASIC FEATURES OF OUR DATA

In this section, we compute and compare the four measures of human capital proposed in the previous section. We use the Public Use Microdata Samples provided by the Census Bureau. The microsamples include information on the schooling, earnings, hours and weeks worked, and employment status of a (practically speaking) random sample of roughly one out of every one hundred Americans in each of the census years 1940,1950,1960,1970, 1980 and 1990.11,12

From the micro data, we compute three items that are inputs into the construction of the various measures of aggregate human capital: (1) the educational attainment distribution (among civilians aged 25-65) for each state at each of the six dates, (2) average weekly earnings for each schooling group at each date, and (3) estimates of the average weekly earnings of somebody with no skill in each state at each date.

Each state's educational attainment distribution is estimated by

11

The 1940, 1950, and 1960 PUMS are 1/100. To economize on computing resources, we work with random subsamples of the later PUMS, arriving at a $1 / 1000$ sample for 1970 and $1 / 200$ samples for 1980 and 1990 . The 1970 subsample was provided by the Census Bureau who derived it from their $5 \%$ State sample. Our 1980 and 1990 subsamples were constructed from the larger $5 \%$ sample by taking only those households whose subsample number had a ones digit equal to 2 .

12

According to the Census Bureau, the 1960, 1970 and 1980 PUMS are self-welghting samples, and we treated them as such in our computations. We also treat our extracts of the 1940 and 1950 PUMS as self-weighting samples, noting that we extract all persons from the raw 1940 data flles and only sample line persons from the raw 1950 data files.

The 1990 PUMS is clearly not a self-weighted sample, so all of our computations for that year weight by the Census Bureau's estimate of the inverse of each person's sampling probability (columns 18-21 of the person record). For example, the regression criteria is to minimize a weighted sum of the squared residuals, where each person's residual is weighted by the inverse of his sampling probability. 
dividing its civilian labor force aged 25-65 into seven schooling categories:
0 . No schooling
1. 0-4 years of elementary school
2. 5-8 years of elementary school
3. 1-3 years of high school
4. High school graduate
5. 1-3 years of college
6. College graduate or more

"Years of schooling" refers to the highest grade completed. ${ }^{13}$ Nursery school and kindergarten are not counted as grades, so an individual qualifies for our no schooling category if he attended nursery school, or kindergarten, or even if he attended - but did not complete - first grade.

Table 4 and Figures $1 \mathrm{a}-1 \mathrm{f}$ display educational attainment distributions for the U.S. civilian labor force aged 25-65 for each of the 6 Census years 1940-90.14,15 In 1940, workers with elght years of schooling or less are in the majority. A majority of the 1950 labor force have completed at least some high school. By 1980, those without a high school diploma are in the minority. By 1990 , a mere $16 \%$ fail to have a high school diploma.

Until 1990, it is not clear whether a response such as "6 years of college" means that the person obtained a bachelor's degree and worked for two years for a higher degree or whether he worked six years to obtain the bachelor's degree.

14 Unless otherwise noted, U.S. is taken to be the sum of the 48 contiguous states.

15 An eighth schooling category, eighth grade graduates, is displayed for the first five Census years. Since eight grade graduates cannot be distinguished from those who attended grade school for 5-7 years in the 1990 PUMS, our computations for all six Census years merge the two categories to form a single category "5-8 years of schooling." 
We will take a worker's average weekly earnings (annual earnings divided by weeks worked, both for the year prior to the Census) to be his or her marginal productivity. Estimates of average weekly earnings are obtained from a subsample of the aged 25-65 civilian labor force (this subsample will be referred to as our "earnings sample"): employed civilians who worked at least 13 weeks in the year prior to the Census (the year for which earnings are reported), who were not self-employed, and who worked more than 30 usual hours per week (in the year of the Census or in the year prior to the Census, depending on the orientation of the Census question in that year). Workers were excluded from the earnings sample if they were currently attending school or if, on average, they earned less than 671982 dollars per week, adjusted for "real economic growth" at $2 \%$ per year. 16 Aged 25-65 civilians who satisfy these selection criteria form our "earnings sample."

\section{III.B. THE LABOR-INCOME-BASED MEASURE OF HUMAN CAPITAL.}

To compute LIHK, we do not approximate the integral (3) directly, but, as suggested by equation (12), divide each state's wage and salary income ${ }^{17}$ by an estimate of the wage in that state of somebody with no skill. The wage of zero skill workers is taken to be the (exponential of the) constant from a

These sample selection criteria are intended to mimic those in the labor literature on wage differentials (see for example Juhn, Murphy and Pierce (1993)). We were unwlling to mimic the minimum weekly earnings cutoff of $\$ 67$ (see Juhn, et al (1993)), as it excluded a significant number of workers in 1940. Unlike Juhn, Murphy and Pierce (1993), we therefore adjust the $\$ 67$ for a $2 \%$ per year growth factor (eg, it is 28.351982 dollars for 1939). 1940-1990 from the BEA (U.S. Department of Commerce, 1984, 1990), we use it as our proxy for production in the state. Population and labor income by state for the years 1969-1990 are obtained from the BEA (U.S. Department of Commerce, 1992). Population for the Census years is obtained from the Bureau of the Census publications (U.S. Bureau of the Census, various issues). 
"Mincer wage regression", estimated from our earnings sample for each state at each date. Our Mincer wage regressions regress log average weekly earnings on years of schooling, years of experience (defined to be age years of schooling - 6), a gender dummy, a race dummy, a marital dummy, a dummy for residence in an SMSA, and a constant. 18

We see two main advantages of using a Mincer regression (over simply computing the sample mean of the wage of zero-schooling workers) in order to estimate the wage of somebody with no skill. The first is that a Mincer regression constant can be estimated even if there are no workers with zero schooling in a particular state. Second, to the extent that the Mincer specification imposes the correct structure on the data, our estimates of the wage of somebody with no skill are more precise because they use information from the entire skill distribution.

Table 1 reports our estimates of the stock of human capital for each of the 48 contiguous states for each census year starting in 1940 . At the bcttom of the table, the geometric average for the United States and for the four Census Regions are reported. We note that the time pattern is quite similar for the four census regions. After a substantial decline in the stock of human capital between 1940 and 1950, human capital increased steadily between 1950 and 1990 (the only exception is a slight decline for the West and the Northeast between 1960 and 1970). We note that the largest increase in the stocks of human capital for all regions took place between 1980 and 1990: aggregate human capital stocks increased by $52 \%$ in that decade, as compared to a $17 \%$ increase for the prior 40 year period.

WHY DO WE CONCLUDE THAT HUMAN CAPITAL DECLINED IN THE 1940s?

A puzzling finding of Table 1 is that the value of human capital experimented a decline during the 1940s. The "technical" reason behind this result is that the wage distribution shrank substantially during that decade.

18 The estimated intercept might therefore be interpreted as the log wage of a rural, unmarried, white male with no experience and no schooling. 
When this happens, the numerator of our measure of human capital falls relative to the denominator so we conclude that the value of human capital falls.

In a sense, we arrive at the right conclusion because when the wage distribution shrinks, the value of becoming educated falls. When the uneducated are as productive as the educated people, then the value of human capital is actually lower.

At some other level, one might argue that we incorrectly say that the value of human capital decreases when the truth is that the uneducated become more productive. Consider, for example, an economy with two types of individuals (Educated and Uneducated). Suppose that their productivities are $\theta(E)$ and $\theta(U)$ respectively, and imagine that the production function can be written as

$$
Y=F[K, \quad \theta(U) N(U)+\theta(E) N(E)]
$$

where $N(E)$ and $N(U)$ are the number of educated and educated respectively. Because we normalize by the wage of the uneducated, our measure of human capital in this case will be:

$$
H=N(U)+\{\theta(E) / \theta(U)\} N(E)
$$

Consider an increase in the productivity of the Educated, $\theta(E)$. Output in our economy increases because the educated are more productive. Our measure of human capital will correctly capture an increase. But consider now an increase in the productivity of the uneducated, $\theta(U)$. Our measure will say that human capital has declined. The reason is that, by assuming that the uneducated are the numeraire (so they are equally productive always and everywhere), we assume that their productivity is always one. When their productivity increases, our measure will conclude that there has been a DECLINE in the value of human capltal AS WELL AS an increase in the overall productivity of human capital. In other words, we rewrite the production function as 


$$
Y=F(K, \quad \boldsymbol{\theta}(U) H),
$$

so when $\theta(U)$ increases, we conclude that $H$ declines that its "technological parameter" $\theta(U)$ has increased.

\section{INTERREGIONAL COMPARISONS}

It is interesting to compare the time pattern of human capital in the different regions (see Figure 2). We note that, while being the region with the highest amount of human capital, the Northeast lost its leading position in the 1980s. The traditional laggard, the South, experimented a large increase in the stock of human capltal during the 1980s, leaving them with the second highest stock by 1990, following the Mldwest. The West has been the region with the lowest amount of human capital ever since 1960.

Figure 3 displays visually the relation between our measure of human capital and its two components (aggregate labor income per capita and the wage of the representative person with zero years of schooling) in the full sample of 48 states. In the horizontal axis we display the log of human capital, $\log (\mathrm{H})$. The vertical axes represents the logarithm of $w(0){ }^{19}$ The figure also displays iso-labor-income lines, which show the combinations of $\log (w(0))$ and $\log (H)$ which yield the same amount of $\log (i n c o m e$ per capita). The lines represent higher amounts of income as we move to the right. We note that, in 1990, the state with the largest amount of human capital was New York, followed by Delaware and Minnesota. At the lowest end, we have Montana and Mississippi, followed by Rhode Island and Wyoming.

Some surprising results immediately arise. First of all, we see that some of the New England states (Rhode Island, New Hampshire and Vermont) have very small amounts of human capital per person, despite having high labor income per caplta. The reason is that zero schooling workers receive huge salaries in those states (note they have the three largest estimates for w(0) 
in 1990). This means that other things equal, in these states workers with higher levels of education are not so much more productive than workers with no schooling. Hence, when measured in units of zero-schooling workers, these states do not have very high stocks of human capital.

Consider now the states with the highest levels of labor income per capita, New York, Delaware, Connecticut, New Jersey and Massachusetts. We note that, in New York and Delaware, the workers with zero schooling have relatively low wages. Hence, our measured human capital for these states is very high. Conversely, the zero-schooling workers in Massachusetts and New Jersey enjoy relatively high base wages, so our measure of $\mathrm{H}$ is lower. Connecticut has a slightly higher level of labor income and an intermediate base wage, w( 0$)$. As a result, our measured human capital is quite high.

At the bottom part of the income scale, we see that Arkansas and South Dakota have extremely low wages for zero schooling people so our measured human capital is high relative to the amount of labor income enjoyed in those states. On the other hand. West Virginia, Montana and Mississippi have high base wages so human capital in those states are low.

Figure 4 reports the same data for 1940. The highest stocks of human capital were found in Delaware, Illinois, New Jersey, Connecticut, New York, Massachusetts and Minnesota. Despite having the highest level of labor income per capita, we do not find that Nevada had large amounts of human capital because their base wage w(0) was also very high. To a smaller degree, the same was true for California.

At the lowest end of the income scale, Mississippi and Arkansas had a relatively high wage for zero schooling people so their measured human capital for 1940 is extremely low. North Carolina, South Dakota, Louisiana, and Alabama closely follow.

Figures 5 and 6 examine the behavior of the two components of human capital for the four Census Regions. Figure 5 displays the behavior of labor income per capita over time. We note a positive trend. We see that the East has always enjoyed the largest levels of labor income while the South has systematically had the lowest.

\section{A MACROECONOMIC INTERPRETATION OF ZERO-SCHOOLING WAGES}

Figure 6 shows the behavior of the wage of the workers with no 
schooling. Under a Cobb Douglas production function, this measure is positively related to the ratio of physical to human capital, $\mathrm{K} / \mathrm{H}$. The figure displays an upward trend for all regions and for all perlods except for the 1980s. During this last decade, the Midwest and the West experienced a net reduction in zero-schooling wages. The South saw a small increase in $w(0)$. There was a large increase in $w(0)$ in the Northeast (this explains why, during this decade, the measured stock of human capital did not increase as much in the Northeast as it did in other regions). We also observe that between 1940 and 1950, the measured zero-schooling wages increased a lot in all four regions. This "explains" (at least mechanically) why we measure a huge decline in the stock of human capital in virtually all states during this decade.

For 1990, the Northeast had the highest value of $w(0)$, followed by the West. A low w(0) corresponds to a low ratio of physical to human capital. This suggests that in 1990 , the Northeast was the region with the highest $\mathrm{K} / \mathrm{H}$ rat10. If we look back at Figure 3, we see that Rhode Island, New Hampshire and Vermont are the states with the three highest levels of $w(0)$. They are followed by Nevada, Massachusetts, New Jersey, Wyoming and Connectlcut. In other words, the six states of New England take six if the top eight positions. This was not true in 1980, when none of them was on the top elght (Rhode Island was the highest New England state in the 13th position and Vermont was the lowest in the $42 \mathrm{nd}) .20$ This suggests that the big New England boom of the 1980 s left this region with a huge stock of physical capital and with a not so large stock of human capital. The end result was large wages for everybody, including the less educated.

Similarly, North Dakota, New Mexico, Oklahoma, Arkansas, Missouri and Tennessee were the states with the lowest $\mathrm{K} / \mathrm{H}$ ratios in 1990 . This explains why our measure of $H$ is not especially low, despite the fact that these states do not have particularly high labor income per capita. 
INCOME PER CAPITA VERSUS INCOME PER WORKER

We used income per capita to compute human capital. Theory suggests the use income per worker instead. Practical problems in measuring workers suggested the use of income per capita. ${ }^{21}$ We do not think that this is an important drawback in general, even though participation and employment rates may have varled substantially both over time and across states.

We computed human capital using labor income per person-weeks worked (divided by the same $w(0) s$ reported in Table 2) and found a very strong correlation with our labor income per capita measure. For example, the correlation for 1990 and 1980 was 0.92 and 0.95 respectively. The lowest correlation coefficient found was 0.83 in 1940 . Hence, we do not think that the use of population rather than employment is a substantial drawback in the computation of human capital.

\section{III.A. VARIABLE WEIGHTS.}

In order to compare the measures existing in the literature with ours, we need to compute these alternative measures using our data set. We start with the variable-weights measure.

Each state's educational attainment distribution is estimated by dividing its civilian labor force aged 25-65 into seven schooling categories. Because our schooling data is categorized in this discrete way, we must approximate the integral (3) with a sum:

What is required is to compute aggregate person-weeks worked (this together with $w(O)$ should divide aggregate labor income). As we only have samples of the population, we need to know the sampling frequency in order to tabulate aggregates. At this point, we are unclear on the sampling frequency of some of the PUMS, but will determine them for later drafts.

Another problem is to obtain a consistent definition of self-employed (self-employment may mean one thing for computation of the national accounts but another thing in the Census). 


$$
h_{i t}=\sum_{j=0}^{6} \theta_{i t}^{j} \eta_{i t}^{j}
$$

where $\theta_{i t}^{j}$ is the average efficiency of a worker (in state $i$ at date $t$ ) in schooling category $j$ and $\eta_{i t}^{j}$ is the share of state $i$ 's workers in category $j$.

To compute aggregate human capital, the weight for category $j$ is taken to be the U.S. average weekly earnings of those workers in our earnings sample and in category $j$ relative to the U.S. average weekly earnings those in the earnings sample with no schooling. This procedure generates a set of seven weights for each of the six Census years. The weights, or efficiency parameters, are displayed Table 5 and graphed in Figure 7. We see that, for the most part, the efficiency parameters are increasing in years of schooling, although the pace at which wages rise with schooling varies over time. Wages rise with schooling fairly slowly in 1950 and 1980, more rapidly in 1940, 70 and 90, and quite rapidly in 1960.

Table 6 displays the estimates of human capital using the variable weights reported in Table 5. The average stock for the United States is pictured in Figure 8 . The most salient feature of this measures is its huge value for 1960.

Figure 9 compares our LIHK with the flexible weight measure of human capital for 1990. We note that correlation is quite low $(0.26$; the correlation was higher in earlier periods, as reported in Table 9). We note a set of six states at the top left part of the Figure (New Hampshire, Utah, Vermont, Montana, Wyoming and Rhode Island) which seems to have a much higher measure of human capital if we use fixed weights than if we use labor-income. In fact, the regression slope (reported in Figure 9) increases substantially if we eliminate these five states from the picture (the regression line when all states are used is the solid line; the dotted line represents the regression line when the six states mentioned above are excluded; the exclusion of these states also changes the correlation coefficient substantially, increasing it to 0.57 ).

\section{I . D. FIXED WEIGHTS}

To construct the fixed weight variable, we simply take the weights for all schooling categories for one of the sample years (we take the weights for 
1970, although the precise year turns out not to matter much).

Table 7 reports the stocks of human capital when fixed weights are imposed over time. Since we see in Table 5 that the 1970 weights were somewhat typical, we used them to compute the fixed weight measure of human capital. ${ }^{22}$ Figure 8 shows the behavior of the U.S. average over time. It displays a steady increase in all decades.

\section{III.E. AVERAGE YEARS OF SCHOOLING.}

Table 8 reports the average years of schooling. As argued in Section 2, this is another fixed-weight measure, where the weights are not determined by the market but, instead, are assumed to be proportional to the number of years of school education. 23 The U.S. average for this measure is displayed in Figure 8. Like the fixed weights measure, this one experiments a steady increase between 1940 and 1990. Figure 10 compares average years of schooling with human capital for 1990. Again we see that there are five states which seem to have less human capital than indicated by their average years of schooling (New Hampshire, Utah, Vermont, Montana, and Wyoming; note

We could use average weights instead. For example, we could compute the average of each of the weights over time. Alternatively, we could estimate a huge panel of all census years and restrict the schooling coefficients to be the same over time. We estimated our fixed weight measure with the weights corresponding to different years and found little difference in the estimated stocks of human capital. As a result, we believe that using fancier fixed weights will not change our estimates of human capital with fixed ways in any substantial manner.

23

The numbers in Table 5 show that the average wage of people with 17 years of schooling are somewhere between two and two and a half larger than the wages of people with three or less years of schooling, despite the fact that they have somewhere between five and infinite times more years of schooling. 
that Rhode Island is no longer an outsider since, on top of having very low amounts of human capital, this state seems to have very low levels of schooling, at least relative to the other states in the same year).

Just to complete the comparisons, Figure 9 displays human capital and labor income per capita in 1990. The correlation is substantial, 0.55, and of the five states that seemed "outliers" before, only New Hampshire seems to remain an outlier (in the sense of having less human capital than "indicated" by its level of income).

Table 9 reports the within-period correlations of all these measures of human capital. We note that, for all periods, the correlation between Fixed Weights, Variable Weights and Schooling is well above 0.95 (and in most cases close to 0.99). ${ }^{24}$ The correlation between any one of these measures and our labor-income-based measure of human capital is substantially smaller.

IV. NONLINEAR LABOR AGGREGATORS

Our analysis thus far has assumed that different type of labor can be aggregated in a linear fashion. Here we show that (1) our labor-income based measure requires only an assumption about the substitutability of workers with for those without schooling, and (2) that our data do not obviously reject this particular perfect substitutability assumption.

Suppose that $J$ different types of labor are aggregated nonlinearly in the aggregate production function. For clarity, however, let's impose some functional form restrictions:

$H(N(0), N(1), \ldots, N(J))=\left[N(0)^{(\psi-1) / \psi}+\phi(N(1), \ldots, N(J))^{(\psi-1) / \psi}\right]^{\psi /(\psi-1)}$

24 The correlations over time are not so strong. We can see in Figure 8 that, for the U.S., fixed weights human capital and average years of schooling increased in all decades. Variable weights human capital, on the other hand, rises in only two out of the five ten-year periods (the 1950 s and the 1980s). 
where $N(j)$ is the number of workers of type $j, \phi$ is homogeneous of degree one, ${ }^{25}$ and $\psi$ is the constant elasticity of substitution of workers without schooling $(\mathrm{N}(0))$ for $\phi$, an aggregate of workers with schooling. ${ }^{26}$

Under the assumption that wages are equated to marginal products, the wage of a person of type $j$, is:

$$
w(j)=F_{H}^{*}(\partial H / \partial N(j))
$$

Labor income is: ${ }^{27}$

$$
\sum_{j=1}^{J} N(j) w(j)=F_{H}^{*}\left(\sum_{j=1}^{J} N(j)[\partial H / \partial N(j)]\right)=F_{H}^{*} H
$$

The second equality follows from the homogeneity of the labor aggregator. It is clear from equations (19) and (20) that, if zero schooling workers are perfect substitutes for workers with skill $(\psi \Rightarrow \infty)$, then a zero-schooling worker's wage is equal to the aggregate marginal product of $h$ :

$$
\mathrm{W}(0)=\mathrm{F}_{\mathrm{H}}^{* 1}=\mathrm{F}_{\mathrm{H}}
$$

Thus if no-skill workers are perfect substitutes for workers with skill $(\psi \Rightarrow$ $\infty)$, then human capital is labor income, normalized by the wage of somebody with no skill.

$$
\sum_{j=1}^{J} N(j) w(j) / w(0)=F_{H}^{*} H / F_{H}=H
$$

25

The assumption of linear-homogeneity is important.

26

$j$ can be thought of as years of schooling, although $j$ can also index many other attributes of skill such as work experience.

27

This assumes a participation rate that is constant across worker types, or an interpretation of $\mathrm{H}$ as the amount of human capital engaged in market production. 
This is exactly the labor income based measure of human capital that we have used throughout the paper. It correctly measures human capital even when various types of labor are aggregated in nonlinear ways, as long as no-skill workers are perfect substitutes for some aggregate of the skilled workers. In terms of our model's parameters, the required assumption is that $\psi=\infty$. The remainder of this subsection empirically assesses this particular perfect substitutability assumption by using our U.S. data to obtain estimates of $\psi$.

If firms are unable to substitute no-skill workers for workers with skill ( $\psi$ is small), then the wage of no-skill workers relative to other workers will be sensitive to exogenous changes in their relative supplies. At the other extreme, perfect substitutability between the two types of workers means that the relative wage depends only on parameters of the production function, not on relative supplies. We use our U.S. data to compare a state's relative supplies with its wage ratio; a negative correlation will be taken as a evidence against the perfect substitutability assumption.

To derive this test more formally, let us assume that various types of skilled workers are perfectly substitutable for each other: ${ }^{28}$

$$
\phi(N(1), \ldots, N(J)) \equiv \sum_{j=1}^{J} \lambda_{j} N_{j}
$$

Define $w(\sim 0)$ to be the average wage of skilled workers:

$$
w(\sim 0)=\frac{\sum_{j=1}^{J} N(j) w(j)}{1-\eta(0)}
$$

Then, holding constant the general level of wages in the state $(w(\sim 0)$ and

While the exact functional relationship between relative wages and relative supplies will depend on this assumption, the basic idea behind the tests - that relative labor demand curves slope down - is mcre general. 
$w_{j} / \lambda_{j}$ for any $\left.j=1 \ldots J\right)$, the elasticity of relative wages with respect to relative supplies is $-1 / \psi$ :

$\ln [w(0) / w(\sim 0)]=\frac{\psi-1}{\psi} \ln \left[w_{j} / \lambda_{j}\right]-\frac{1}{\psi} \ln \frac{\eta(0)}{1-\eta(0)}-\frac{\psi-1}{\psi} \ln w(\sim 0)$,

Under the assumption that, holding constant ln $w(\sim 0)$, relative supplies are uncorrelated with $w_{j} / \lambda_{j}$ (one can think of this ratio as indicative of the general level of wages in the economy), one can regress in $w(0)$ on $\ln w(\sim 0)$ and the $\log$ of the relative supplies and the coefficient on the relative supplies is $-1 / \psi$. If relative supplies fail to be correlated with relative wages, then we fail to reject the perfect substitutability hypothesis $(\psi=$ $\infty)$.

Table 10 presents regressions of relative wages on relative supplies. In the top panel, $w(0)$ is measured as the within-state average weekly earnings of those workers in our earnings sample with fewer than five years of schooling. $w(\sim 0)$ is taken to be the average weekly earnings of all other workers in our earnings sample.

We find that, contrary to the perfect substitutability hypothesis, relative wages and relative supplies are negatively correlated in $f$ ive of the six cross-sections of states. However, the implied elasticity estimates (1 over the estimated coefficient on relative supplies) are quite high: $6,7,9$, $\infty, 45$, and 25; relative wages are not very responsive to relative supplies.

For our 1970, 80 and 90 earnings subsamples of the Census PUMS, there are a few states who do not have any workers with fewer than five years of schooling. Those states are: Nebraska (1970), North Dakota (1990), South Dakota (1970), Utah (1970), Vermont (1980, 1990) and Wyoming (1970). As an alternative to excluding states because of their zero cell size, the bottom panel of Table 10 displays estimates of equation (25) that use the Mincer regression constant as an estimate of $\ln w(0)$ and the within-state average weekly earnings of our earnings sample as an estimate of $w(\sim 0)$. We see that, using this alternative estimate of $w(0)$, one cannot reject the perfect 
substitutability hypothesis. ${ }^{29}$ Point estimates of $-1 / \psi$ are negative in only three of six decades and, in those three decades, the implied elasticity estimates are quite large: 81,90 and 27.

Table 10 regressed relative wages on relative supplies, whereas equation (25) suggests that the average wage of skilled workers w( 0) should also be included as a RHS variable. When we do so, the implied elasticities are slightly larger than those reported in Table 10, so we limit our presentation to the simpler specification found there, which is less favorable to the perfect substitutability hypothesis.

It is therefore not clear that we should be uncomfortable with our assumption that workers without schooling are perfect substitutes for those with schooling. As a result, we are comfortable with our labor-income-based measure of human capital because it is robust to any nonlinear aggregation schemes.

We also note that the lower panel's estimate of in w(0), the Mincer regression constant, coincides with the estimates that we used to construct our labor income based measure of human capital. 
VI. SUMMARY AND CONCLUSIONS.

In this paper we discuss and actually construct various measures of the value of human capital in a cross-section of U.S. States for 6 census years.

We argue that allowing different people to have different weights in our measures of human capital is a good idea for at least two reasons: first, schooling in different places and at different times has different qualities. Second, different types (and amounts) of schooling has different relevance in different places and points in time. To capture the concepts of schooling quality and schooling relevance, our measure of human capital must allow for variable weights.

We also argued that the only sensible numeraire is a zero-schooling worker. The reason is that, if schooling has different quality and relevance across states and over time, then any positive amount of schooling will affect people in different ways. Hence, workers with any positive amount of schooling will be different and, as a result, will not be good candidates for a numeraire.

We note that, unlike other measures of aggregate human capital, ours does not require the assumption of infinite elasticity of substitution across all types of workers. We only need perfect elasticity between the zero-schooling workers and the rest. We test this assumption and find little evidence of finite elasticities.

We argue that a sensible measure of the value of human capital is the ratio of total labor income per capita to the wage of a person with zero years of schooling. The reason for that is that total labor income not only incorporates human capital, but also physical capital: given human capital, regions with higher physical capital will tend to have higher wages for all workers and, therefore, higher labor income. We find that one way to net out the effect of aggregate physical capital on labor income is to divide labor income by the wage of a zero-schooling worker.

To compute the wage of a zero-schooling worker, we regress, state by state and year by year, individuals' average weekly earnings on their schooling and a number of characteristics (like experience, sex, race, and marital status). The constant term is taken to be the wage of a worker in the corresponding state and in the corresponding year with zero schooling 
(and zero experience).

Because our measure of human capital is not mechanically tied to the educational attainment of the work force, we are able to actually test the proposition that the increase in educational attainment over the period is indicative of an increase in the amount of human capital. We find that our measure of human capital is positively correlated with other measures of human capital, like the average years of schooling. We find, however, that the correlation is far from perfect, and that some states which have lots of schooling do not have very high stocks of human capital. This was the case, for example, for some of the New England states in 1990. The period 1940-1980 was a period of fairly substantial increase in average years of schooling, but not human capital.

For the average U.S. state, our measure suggests that the value of human capital during the $: 380 \mathrm{~s}$ grew at a much larger rate than schooling. The reason has to do with movements in the relative productivities of the different workers: in some sense, some workers and some types of schooling became a lot more relevant in the 1980 s and, as a result, measured human capital increased. 
TABLE 1: LABOR INCOME-BASED HUMAN CAPITAL (Logs)

\begin{tabular}{|c|c|c|c|c|c|c|c|}
\hline & & 1940 & 1950 & 1960 & 1970 & 1980 & 1990 \\
\hline 1 & AL & 3.350 & 3.091 & 3.593 & 3.712 & 3.851 & 4.409 \\
\hline 2 & $A Z$ & 3.702 & 3.384 & 3.684 & 3.730 & 3.828 & 4. 341 \\
\hline 3 & $\mathrm{AR}$ & 3.134 & 2.786 & 3.330 & 3.642 & 3.640 & 4. 354 \\
\hline 4 & $C A$ & 3.827 & 3.453 & 3.902 & 3.877 & 4.116 & 4.529 \\
\hline 5 & $\mathrm{CO}$ & 3.731 & 3.442 & 3.747 & 3.662 & 4.141 & 4.669 \\
\hline 6 & CT & 4.083 & 3.715 & 4. 121 & 3.889 & 4.108 & 4.578 \\
\hline 7 & $D E$ & 4.474 & 3.731 & 4.256 & 4.345 & 4.482 & 4.694 \\
\hline 8 & FL & 3.551 & 3.346 & 3.512 & 3.656 & 3.836 & 4.410 \\
\hline 9 & GA & 3.488 & 3.312 & 3.633 & 3.753 & 4.056 & 4.548 \\
\hline 10 & ID & 3.711 & 2.800 & 3.424 & 3.512 & 3.633 & 4.297 \\
\hline 11 & IL & 4.263 & 3.729 & 3.961 & 3.780 & 3.912 & 4.570 \\
\hline 12 & IN & 3.812 & 3.407 & 3.585 & 3.644 & 3.724 & 4.459 \\
\hline 13 & IA & 3.742 & 3.331 & 3.456 & 3.412 & 3.690 & 4.265 \\
\hline 14 & KS & 3.588 & 3.342 & 3.571 & 3.632 & 3.841 & 4.460 \\
\hline 15 & $K Y$ & 3. 388 & 2.973 & 3.352 & 3.557 & 3.639 & 4.290 \\
\hline 16 & LA & 3.282 & 3.205 & 3.550 & 3.317 & 3.572 & 4.252 \\
\hline 17 & ME & 3.585 & 3.092 & 3.662 & 3.369 & 3.792 & 4.362 \\
\hline 18 & MD & 4.017 & 3.642 & 4.008 & 3.973 & 4.163 & 4.637 \\
\hline 19 & MA & 4.048 & 3.801 & 3.852 & 3.754 & 4.134 & 4.399 \\
\hline 20 & MI & 3.864 & 3.535 & 3.747 & 3.716 & 3.879 & 4.534 \\
\hline 21 & $\mathbf{M N}$ & 4.052 & 3.404 & 3.733 & 3.597 & 4.173 & 4.712 \\
\hline 22 & MS & 2.688 & 2.728 & 3.191 & 3.138 & 3.671 & 3.924 \\
\hline 23 & MO & 3.899 & 3.603 & 3.786 & 3.842 & 3.967 & 4.666 \\
\hline 24 & MT & 3.551 & 3.200 & 3. 376 & 3.235 & 3.605 & 3.893 \\
\hline 25 & $\mathrm{NE}$ & 3.925 & 3.501 & 3.619 & 3.646 & 3.752 & 4. 392 \\
\hline 26 & NV & 3.561 & 4.106 & 3.756 & 3.561 & 3.904 & 4. 301 \\
\hline 27 & NH & 3.646 & 3.332 & 3.409 & 3.717 & 3.961 & 4.045 \\
\hline 28 & NJ & 4.088 & 3.710 & 3.987 & 3.570 & 4.012 & 4.412 \\
\hline 29 & NM & 3.402 & 3.386 & 3.920 & 4.096 & 3.758 & 4.448 \\
\hline 30 & NY & 4.059 & 3.855 & 4.082 & 4.020 & 4.247 & 4.735 \\
\hline 31 & NC & 3.180 & 3.229 & 3.660 & 3.741 & 4.045 & 4.574 \\
\hline 32 & ND & 3.725 & 3.280 & 3.355 & 3.845 & 3.557 & 4.417 \\
\hline 33 & $\mathrm{OH}$ & 4.001 & 3.569 & 3.769 & 3.692 & 3.852 & 4.582 \\
\hline 34 & OK & 3.623 & 3.404 & 3.818 & 3.906 & 3.916 & 4.436 \\
\hline 35 & $\mathrm{OR}$ & 3.642 & 3.259 & 3.430 & 3.387 & 3.671 & 4.332 \\
\hline 36 & PA & 3.841 & 3.515 & 3.856 & 3.838 & 3.876 & 4.591 \\
\hline 37 & RI & 3.914 & 3.787 & 3.573 & 3.125 & 3.773 & 3.969 \\
\hline 38 & $\mathrm{SC}$ & 3.207 & 2.930 & 3.531 & 3.477 & 3.831 & 4.282 \\
\hline 39 & SD & 3.576 & 3.708 & 3.677 & 3.665 & 3.548 & 4. 167 \\
\hline 40 & TN & 3.539 & 3.260 & 3.639 & 3.659 & 3.965 & 4.581 \\
\hline 41 & TX & 3.780 & 3.600 & 3.950 & 3.782 & 4.031 & 4.499 \\
\hline 42 & UT & 3.741 & 3.207 & 3.719 & 3.412 & 3.603 & 4.151 \\
\hline 43 & VT & 3.959 & 3.198 & 3.745 & 3.801 & 3.918 & 4.031 \\
\hline 44 & VA & 3.733 & 3.375 & 3.958 & 4.005 & 4. 176 & 4.671 \\
\hline 45 & WA & 3.789 & 3.381 & 3.726 & 3.475 & 3.773 & 4.409 \\
\hline 46 & WV & 3. 387 & 2.954 & 3.495 & 3.404 & 3.720 & 4.069 \\
\hline 47 & WI & 3.845 & 3.461 & 3.610 & 3.552 & 3.706 & 4.475 \\
\hline 48 & $W Y$ & 3.642 & 3.323 & 3.627 & 3.630 & 3.738 & 4.020 \\
\hline
\end{tabular}


TABLE 1 (cont): LABOR INCOME-BASED HUMAN CAPITAL (Logs)

\begin{tabular}{|c|c|c|c|c|c|c|}
\hline $\begin{array}{c}\text { US Mean } \\
\text { S.D. }\end{array}$ & $\begin{array}{l}3.701 \\
0.313\end{array}$ & $\begin{array}{l}3.383 \\
0.287\end{array}$ & $\begin{array}{l}3.686 \\
0.224\end{array}$ & $\begin{array}{l}3.661 \\
0.236\end{array}$ & $\begin{array}{l}3.871 \\
0.206\end{array}$ & $\begin{array}{l}4.393 \\
0.216\end{array}$ \\
\hline Northeast & 3.914 & 3.556 & 3.810 & 3.676 & 3.980 & 4.347 \\
\hline South & 3.489 & 3.223 & 3.655 & 3.692 & 3.912 & 4.414 \\
\hline Midwest & 3.858 & 3.489 & 3.656 & 3.669 & 3.800 & 4.475 \\
\hline West & 3.664 & 3.358 & 3.665 & 3.598 & 3.797 & 4. 308 \\
\hline
\end{tabular}

Notes to Table 1:

(1) This table reports the logarithm of the computed stocks of human capital based on labor income. See the text for a discussion of the construction of such a measure.

(2) The four regions are defined by the Bureau of the Census. 
TABLE 2: $\log (w(0))$ (Mincer regression Constants)

\begin{tabular}{|c|c|c|c|c|c|c|c|}
\hline & & 1940 & 1950 & 1960 & 1970 & 1980 & \\
\hline 1 & AL & 1.8334 & 3.2157 & 3.3325 & 3.8717 & 4.6016 & 4.652 \\
\hline 2 & $A Z$ & 2. 1244 & 3.2247 & 3.5279 & 4.0624 & 4.7852 & 4.794 \\
\hline 3 & $A R$ & 1.7153 & 3.2347 & 3. 3503 & 3.7611 & 4.6694 & 4.561 \\
\hline 4 & $\mathrm{CA}$ & 2. 4252 & 3.5968 & 3.6095 & 4. 1481 & 4.7202 & 4.882 \\
\hline 5 & $\mathrm{CO}$ & 2.0172 & 3.3053 & 3.5380 & 4. 1915 & 4.6632 & 4.652 \\
\hline 6 & CT & 2. 3335 & 3.4009 & 3.4043 & 4. 1668 & 4.7619 & 5.028 \\
\hline 7 & $\mathrm{DE}$ & 1.7912 & 3. 4034 & 3.2945 & 3.7196 & 4. 3684 & $4.796 \varepsilon$ \\
\hline 8 & FL & 2. 1146 & 3.2683 & 3.5814 & 4. 1062 & 4.6821 & 4.730 \\
\hline 9 & GA & 1.8362 & 3.1538 & 3. 3974 & 4.0153 & 4.5411 & 4.728 \\
\hline 10 & ID & 1.8407 & 3.7433 & 3.5896 & 4.0912 & 4.8254 & 4.668 \\
\hline & IL & 1.9637 & 3. 3917 & 3.5523 & 4.2635 & 4.8927 & 4.8276 \\
\hline 12 & IN & 2.1105 & .5276 & 3.7316 & 4.2174 & 4.9206 & 4.749 \\
\hline 3 & IA & 1.7255 & .1631 & 3.5246 & 4.2143 & 4.8637 & 4.802 \\
\hline 14 & KS & 1.8400 & .2345 & 3.4873 & 4.0055 & 4. 7917 & 4.694 \\
\hline 5 & KY & 1.8 & 2 & 3.5 & 4.0276 & 4. 7965 & 4.726 \\
\hline 16 & LA & 49 & 2 & 3.4270 & 4. 3008 & 5.0543 & 4.754 \\
\hline 17 & $\mathrm{ME}$ & 2.1 & 53 & 3.4740 & 4.3 & 4.6530 & 4.766 \\
\hline 18 & MD & 2.12 & .2763 & 3.2856 & 3.9 & 4. 5379 & 4.7470 \\
\hline 9 & $\mathrm{MA}$ & 2. 1820 & 4 & 3.5 & 4.2 & 4.6470 & 5.1173 \\
\hline 20 & MI & 3299 & 6 & 3.6 & 4.2 & 4.8604 & 4.7701 \\
\hline 21 & $\mathbf{M N}$ & 1.6 & 9 & 3.4 & 4.2 & 4. 5538 & $4.627^{\circ}$ \\
\hline 22 & MS & 2.0083 & .1770 & 4068 & 4.24 & 4.6112 & 4.8 \\
\hline 23 & MO & 1.8597 & 3. 1653 & 3.4809 & 4.0291 & 33 & 4. \\
\hline 24 & MT & 2.2706 & 3.4960 & 3.6974 & 4. 3392 & 4.8897 & 4 \\
\hline 25 & NE & 1.4963 & 3.0445 & 3. 4587 & 4.0517 & 4.8364 & 4.74 \\
\hline 26 & NV & 2.8027 & 2.9964 & 3.8750 & 4.6122 & 5.0516 & 5.1290 \\
\hline 27 & NH & 2. 2688 & 3.3920 & 3.8028 & 4.0308 & 4.6107 & 5.2224 \\
\hline 28 & $\mathrm{NJ}$ & 2.2651 & 3.3503 & 3.4771 & 4.4113 & 4.7631 & 5.1098 \\
\hline 29 & NM & 2.0153 & 3. 1886 & 3.2478 & 3.5335 & 4.7639 & 4.5537 \\
\hline 30 & NY & 2.2445 & 3. 3261 & 3.5050 & 4.0906 & 4.5560 & 4.7804 \\
\hline 31 & NC & 2. 1200 & 3.2054 & 3.2963 & 3.9809 & 4.5032 & 4.6387 \\
\hline 32 & ND & 1.4952 & 3.0041 & 3.4332 & 3.6075 & 4.9318 & 4.5359 \\
\hline 33 & $\mathrm{OH}$ & 2.1186 & 3.4508 & 3.6465 & 4.2550 & 4.8688 & 4.6728 \\
\hline 34 & OK & 1.6970 & 3.0668 & 3.1999 & 3.7270 & 4.6867 & 4.5620 \\
\hline 35 & OR & 2.3082 & 3.6275 & 3.8405 & 4.4205 & 4. 9977 & 4.8399 \\
\hline 36 & PA & 2.2458 & 3.4465 & 3.4948 & 4.0697 & 4.8032 & 4.6612 \\
\hline 37 & RI & 2.2905 & 3.2455 & 3.7610 & 4.7700 & 4.8471 & 5.2948 \\
\hline 38 & SC & 2.0761 & 3.4253 & 3.3615 & 4. 1857 & 4.6637 & 4.8486 \\
\hline 39 & SD & 1.6199 & 2.5608 & 3.0669 & 3.6941 & 4. 7587 & 4.7017 \\
\hline 40 & TN & 1.7844 & 3. 1599 & 3.3216 & 4.0202 & 4.5590 & 4.5794 \\
\hline 41 & $T X$ & 1.7117 & 3.0956 & 3. 1669 & 3.9839 & 4.7104 & 4.6997 \\
\hline 42 & UT & 1.9975 & 3.5279 & 3.5115 & 4.3137 & 4.9494 & 4.9169 \\
\hline 43 & VT & 1.7750 & 3. 3890 & 3.3296 & 3.9303 & 4.5448 & 5.1383 \\
\hline 44 & VA & 2.0356 & 3. 3089 & 3. 1735 & 3.8337 & 4.5053 & 4.6945 \\
\hline 45 & WA & 2. 3041 & 3.5701 & 3.6209 & 4.4200 & 5.0033 & 4.8843 \\
\hline 46 & WV & 2.2830 & 3.6894 & 3.5396 & 4.2393 & 4. 7684 & 4.8320 \\
\hline 47 & WI & 1.9897 & 3. 3784 & 3.6446 & 4.2555 & 4. 9517 & 4.7341 \\
\hline & & 2.1705 & .5671 & 3.6766 & 4.1321 & 5.1745 & 5.1176 \\
\hline
\end{tabular}


TABLE 2 (cont): $\log (w(0))$ (Mincer regression Constants)

\begin{tabular}{|c|c|c|c|c|c|c|}
\hline $\begin{array}{l}\text { US Mean } \\
\text { S.D. }\end{array}$ & $\begin{array}{l}2.0287 \\
0.2615\end{array}$ & $\begin{array}{l}3.3184 \\
0.2084\end{array}$ & $\begin{array}{l}3.4865 \\
0.1779\end{array}$ & $\begin{array}{l}4.1108 \\
0.2415\end{array}$ & $\begin{array}{l}4.7537 \\
0.1689\end{array}$ & $\begin{array}{l}4.7999 \\
0.1849\end{array}$ \\
\hline North & 2. 1971 & 3. 3675 & 3.5387 & 4.2256 & 4.6874 & 5.0132 \\
\hline South & 1.9448 & 3.2721 & 3. 3528 & 3. 9971 & 4.6411 & 4.7152 \\
\hline Midwest & 1.8508 & 3.2315 & 3.5104 & 4.0892 & 4.8258 & 4.7022 \\
\hline West & 2.2069 & 3.4403 & 3.6122 & 4. 2058 & 4.8931 & 4. 8553 \\
\hline
\end{tabular}

Notes to Table 2:

(1) This table reports the logarithm of the computed wage of zero-schooling workers. See the text for a discussion of the construction of such measure.

(2) The four regions are defined by the Bureau of the Census. 
TABLE 3: WAGE INCOME PER CAPITA (logs)

\begin{tabular}{|c|c|c|c|c|c|c|c|}
\hline & & 1940 & 1950 & 1960 & 1970 & 1980 & 1990 \\
\hline 1 & $\mathrm{AL}$ & 5.1836 & 6.3070 & 6.9262 & 7.5840 & 8.4530 & 9.0625 \\
\hline 2 & $A Z$ & 5.8271 & 6.6094 & 7.2121 & 7.7927 & 8.6133 & 9.1360 \\
\hline 3 & $\mathrm{AR}$ & 4.8501 & 6.0209 & 6.6810 & 7.4031 & 8. 3100 & 8.9163 \\
\hline 4 & $\mathrm{CA}$ & 6.2527 & 7.0505 & 7.5123 & 8.0255 & 8.8364 & 9.4118 \\
\hline 5 & $\mathrm{CO}$ & 5.7484 & 6.7477 & 7.2859 & 7.8539 & 8.8048 & 9.3225 \\
\hline 6 & $\mathrm{CT}$ & 6.4174 & 7.1165 & 7.5254 & 8.0558 & 8.8702 & 9.6065 \\
\hline 7 & $\mathrm{DE}$ & 6.2659 & 7.1353 & 7.5507 & 8.0648 & 8.8510 & 14 \\
\hline 8 & FL & 5.6 & 6.6146 & 7.0939 & 31 & 8.5187 & \\
\hline 9 & GA & 5 & 664 & 310 & & & 72 \\
\hline 10 & ID & 5.5 & 6.5438 & 7.0137 & 7.6 & 8.4 & 54 \\
\hline 11 & IL & 6.2 & 7.1213 & 7.5133 & 8. & 8.8 & \\
\hline 12 & IN & 5.9229 & 6.9354 & 7.3171 & 7.8623 & 8.6448 & 91 \\
\hline 13 & IA & 5.4676 & 6.4948 & 6.9812 & 7.6271 & 8.5538 & 9.0675 \\
\hline 14 & KS & 5.4284 & 6.5774 & 7.0592 & 7.6384 & 8.6329 & 9.1548 \\
\hline 15 & KY & 5.2423 & 6.3471 & 6.8627 & 7.5849 & 8.4364 & 9.0171 \\
\hline 16 & LA & 5.4176 & 6.5056 & 6.9774 & 7.6183 & 8.6272 & 9.0065 \\
\hline 17 & ME & 5.7545 & 6.6175 & 7.1368 & 7.6837 & 8.4455 & 9.1286 \\
\hline 18 & $\mathrm{MD}$ & 6.1405 & 6.9192 & 7.2945 & 7.9043 & 8.7014 & 9.3843 \\
\hline 19 & MA & 6.2300 & 7.0335 & 7.4528 & 8.0012 & 8.7810 & 9.5170 \\
\hline 20 & MI & 6.1942 & 7.0974 & 7.4014 & 7.9473 & 8.7403 & 9.3048 \\
\hline 21 & MN & 5.7137 & 6.7001 & 7.1790 & 7.8436 & 8.7268 & 9.3402 \\
\hline 22 & MS & 4.6967 & 5.9059 & 6.5988 & 7.3878 & 8.2828 & 8.8165 \\
\hline 23 & MO & 5.7593 & 6.7689 & 7.2673 & 7.8712 & 8.6482 & 9.2301 \\
\hline 24 & MT & 5.8220 & 6.6963 & 7.0742 & 7.5752 & 8. 4953 & 8.8633 \\
\hline 25 & $\mathrm{NE}$ & 5.4222 & 6.5458 & 7.0780 & 7.6 & 8.5885 & 9.1395 \\
\hline 26 & NV & 6.3647 & 7.1034 & $7.6 !$ & 8. & 8.9 & 9.4306 \\
\hline 27 & NH & 5.9153 & 6.7247 & 7.2125 & 7.7 & 8.5721 & 9.2673 \\
\hline 28 & NJ & 6.3540 & 7.0607 & 7.4643 & 7. & 8.7759 & 9.5218 \\
\hline 29 & NM & 5.4177 & 6.5750 & 7.1683 & 7.6 & 8.5226 & 9.0024 \\
\hline 30 & NY & 6.3 & 7.1811 & 7.5877 & 8. & 8.8035 & 155 \\
\hline 31 & NC & 5.3 & 6.4344 & 6.9 & 7 . & 8.5491 & 134 \\
\hline 32 & ND & 5.2210 & 6.2848 & 6.7890 & 7.4 & 8.4892 & 530 \\
\hline 33 & $\mathrm{OH}$ & 6.1202 & 7.0198 & 7.4160 & 7.9472 & 8.7216 & 9.2557 \\
\hline 34 & OK & 5.3209 & 6.4715 & 7.0187 & 7.6337 & 8.6036 & 8.9986 \\
\hline 35 & OR & 5.9508 & 6.8866 & 7.2706 & 7.8081 & 8.6694 & 9.1720 \\
\hline 36 & PA & 6.0875 & 6.9622 & 7.3516 & 7.9087 & 8.6792 & 9.2529 \\
\hline 37 & RI & 6.2047 & 7.0331 & 7.3344 & 7.8955 & 8.6203 & 9.2643 \\
\hline 38 & SC & 5.2835 & 6.3560 & 6.8930 & 7.6633 & 8.4950 & 9.1315 \\
\hline 39 & SD & 5.1965 & 6.2696 & 6.7443 & 7.3597 & 8.3076 & 8.8694 \\
\hline 40 & TN & 5.3234 & 6.4208 & 6.9606 & 7.6793 & 8.5247 & 9.1610 \\
\hline 41 & TX & 5.4923 & 6.6963 & 7.1170 & 7.7664 & 8.7420 & 9.1996 \\
\hline 42 & UT & 5.7387 & 6.7357 & 7.2306 & 7.7266 & 8.5524 & 9.0682 \\
\hline 43 & VT & 5.7340 & 6.5870 & 7.0754 & 7.7315 & 8.4631 & 9.1700 \\
\hline 44 & VA & 5.7687 & 6.6842 & 7.1322 & 7.8393 & 8.6823 & 9.3658 \\
\hline 45 & WA & 6.0939 & 6.9520 & 7.3473 & 7.8951 & 8.7770 & 9.2942 \\
\hline 46 & WV & 5.6706 & 6.6434 & 7.0348 & 7.6439 & 8.4891 & 8.9012 \\
\hline 47 & WI & 5.8350 & 6.8398 & 7.2552 & 7.8077 & 8.6585 & 9.2093 \\
\hline 48 & $W Y$ & 5.8132 & 6.8904 & 7.3041 & 7.7621 & 8.9128 & 9.1378 \\
\hline
\end{tabular}


TABLE 3 (cont): WAGE INCOME PER CAPITA (logs)

\begin{tabular}{lllllll}
\multicolumn{1}{r}{ US Mean } & $\mathbf{5 . 7 2 9 9}$ & 6.7018 & 7.1733 & 7.7727 & $\mathbf{8 . 6 2 4 7}$ & 9.1929 \\
\multicolumn{1}{c}{ S.D. } & 0.4128 & 0.2994 & 0.2409 & 0.1878 & 0.1561 & 0.1891 \\
& & & & & & \\
Northeast & 6.1112 & 6.9240 & 7.3490 & 7.9018 & 8.6678 & 9.3604 \\
South & $\mathbf{5 . 4 3 4 1}$ & 6.4955 & 7.0080 & 7.6891 & $\mathbf{8 . 5 5 3 9}$ & 9.1301 \\
Midwest & $\mathbf{5 . 7 0 9 0}$ & 6.7212 & 7.1667 & 7.7582 & $\mathbf{8 . 6 2 6 4}$ & 9.1776 \\
West & $\mathbf{5 . 8 7 0 9}$ & 6.7991 & 7.2773 & 7.8042 & $\mathbf{8 . 6 9 0 7}$ & 9.1640
\end{tabular}

Notes to Table 3:

(1) This table reports the logarithm of labor income per capita.

(2) Source: Bureau of Economic Analysis, 1980, 1990.

(3) The four regions are defined by the Bureau of the Census. 
TABLE 4: EDUCATIONAL ATTAINMENT FOR THE U.S., 1940-1990

\begin{tabular}{lllllll} 
Schooling & \multicolumn{7}{c}{ Year } \\
Category & 1940 & 1950 & 1960 & 1970 & 1980 & 1990 \\
& & & & & & \\
No School & 0.028 & 0.016 & 0.008 & 0.006 & 0.004 & 0.007 \\
$0-4$ yrs & 0.095 & 0.073 & 0.038 & 0.023 & 0.012 & 0.007 \\
$5-7$ yrs & 0.177 & 0.150 & 0.096 & 0.070 & 0.036 & 0.034 \\
8 yrs & 0.270 & 0.196 & 0.163 & 0.099 & 0.044 & \\
$1-3$ yrs HS & 0.160 & 0.186 & 0.207 & 0.201 & 0.131 & 0.109 \\
4 yrs HS & 0.148 & 0.219 & 0.275 & 0.346 & 0.377 & 0.300 \\
$1-3$ yrs Col & 0.060 & 0.080 & 0.104 & 0.116 & 0.184 & 0.289 \\
$4+$ yrs Col & 0.062 & 0.080 & 0.108 & 0.138 & 0.212 & 0.254
\end{tabular}

\section{Notes}

(1) The schooling categories "5-7 yrs" and "8 yrs" are not distinguished in the 1990 Census. The two categories are therefore merged in our computations for all Census years. 
TABLE 5: ESTIMATES OF $\theta(t, s)$

\begin{tabular}{lccccccc} 
Year & 0 & \multicolumn{7}{c}{ Schooling Category } \\
1940 & 1 & 0.93 & 1.26 & 1.41 & 1.55 & 1.77 & 2.28 \\
1950 & 1 & 1.02 & 1.18 & 1.29 & 1.36 & 1.56 & 1.88 \\
1960 & 1 & 1.01 & 1.31 & 1.52 & 1.71 & 2.30 & 3.55 \\
1970 & 1 & 0.97 & 1.19 & 1.32 & 1.46 & 1.73 & 2.36 \\
1980 & 1 & 1.06 & 1.18 & 1.26 & 1.37 & 1.53 & 2.03 \\
1990 & 1 & 0.99 & 1.11 & 1.21 & 1.37 & 1.62 & 2.42 \\
Notes to Table $5:$ & &
\end{tabular}


TABLE 6: HUMAN CAPITAL WITH VARIABLE WEIGHTS (HKVW, LOgS)

\begin{tabular}{|c|c|c|c|c|c|c|c|}
\hline & AL & $\begin{array}{r}1940 \\
0.24307\end{array}$ & $\begin{array}{r}1950 \\
0.22199\end{array}$ & $\begin{array}{r}1960 \\
0.51428\end{array}$ & $\begin{array}{r}1970 \\
0.38992\end{array}$ & $\begin{array}{r}1980 \\
0.37725\end{array}$ & \\
\hline 2 & $A Z$ & 34186 & 0.30172 & 0.60918 & 0.46171 & 0.41871 & - \\
\hline 3 & AR & .25411 & 0.21454 & 0.50466 & 0.37638 & 0.36597 & 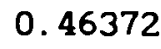 \\
\hline 4 & $\mathrm{CA}$ & .38536 & 0.31006 & 190 & 0.47027 & 3382 & 372 \\
\hline 5 & $\mathrm{CO}$ & .36800 & .30177 & 0.66645 & 0.49064 & .45263 & r \\
\hline 6 & $\mathrm{CT}$ & .33610 & .28287 & 0.60395 & 0.44626 & 0.43070 & res \\
\hline 7 & $\mathrm{DE}$ & .33986 & .27311 & 0.62800 & 0.45145 & 359 & \\
\hline 8 & FL & .30484 & 0.26474 & 0.57909 & 0.41973 & 0.40205 & 0.4969 \\
\hline 9 & GA & .24708 & 0.21774 & 0.50834 & 0.38861 & 0.38645 & 0. \\
\hline 10 & ID & .36326 & 0.29425 & 0.61570 & 0.42085 & 0.42193 & 0.5027 \\
\hline 1 & IL & .34096 & 0.28100 & 0.58589 & 0.42676 & 0.41158 & 0.5267 \\
\hline 12 & IN & .34418 & 0.27939 & 0.57982 & 0.41193 & 0.38394 & 0.4761 \\
\hline 3 & IA & .35491 & 0.28402 & 0.58267 & 0.43675 & 0.40345 & 0.5036 \\
\hline 4 & KS & .36238 & 0.29536 & 0.62631 & 0.45621 & 0.41902 & 0.5302 \\
\hline 15 & $K Y$ & .26752 & 0.23014 & 0.51047 & 0.37441 & 0.36016 & 0.4568 \\
\hline 16 & LA & .24240 & 0.22259 & 0.52936 & 0.38629 & 0.39036 & 0.4790 \\
\hline 7 & ME & 34342 & 0.26638 & 0.55851 & 0.41889 & 0.39811 & 0.5021 \\
\hline & MD & 31105 & 0.27074 & 59001 & & 0.4 & 0. \\
\hline & MA & 1 & 7 & 5 & & 0. & \\
\hline 20 & MI & 2 & 1 & 1 & 30 & 0.40 & 0. \\
\hline 21 & $\mathbf{M N}$ & 2 & 16 & 5 & 21 & 0.42 & 0. \\
\hline 22 & 15 & 6 & 3 & 2 & 55 & 0.37 & \\
\hline 23 & MO & 0 & 18 & 7 & 75 & 0.39 & 0. \\
\hline 4 & IT & 2 & 57 & 1 & 0.4 & 0.43 & 0. \\
\hline 5 & $\mathrm{E}$ & 3 & 93 & 7 & & 0.42 & 0. \\
\hline 26 & IV & 23 & 16 & 7 & 0 . & 0.39 & 0. \\
\hline 27 & $\mathrm{NH}$ & 5 & 7 & 6 & 0. & 2 & 0. \\
\hline 8 & NJ & 3 & & & & & \\
\hline 29 & NM & & & & & & \\
\hline 30 & IY & & & & & & \\
\hline 31 & $\mathrm{NC}$ & & & & & & \\
\hline 32 & ND & & & & & & \\
\hline 33 & ( & & & & & & \\
\hline 34 & OK & & & & & & \\
\hline 35 & OR & 1 & & & & & \\
\hline 36 & $P A$ & & & & & & \\
\hline & RI & & & & & & \\
\hline 38 & SC & 236 & & & & & \\
\hline 39 & SD & 0.33594 & 0.27219 & 0.56 & 0.37449 & & \\
\hline 40 & TN & .27692 & 0.23913 & 0.50 & 0.3 & 0.5 & \\
\hline 41 & TX & .31900 & 0.26544 & 0.58096 & 0.41146 & 0.40580 & 0.5 \\
\hline 42 & UT & .39733 & 0.32866 & 0.69160 & 0.48678 & 0.44835 & 0.5 \\
\hline 43 & VT & 34491 & 0.28997 & 0.58096 & 0.41461 & 0.41245 & 0.53152 \\
\hline 44 & VA & .28161 & 0.25694 & 0.55983 & 0.41301 & 0.41421 & 0.5325 \\
\hline 45 & WA & .37278 & 0.31416 & 0.65502 & 0.45097 & 0.43551 & 0.5525 \\
\hline 46 & WV & .30218 & 0.24850 & 0.54265 & 0.40301 & 0.37163 & 0.45939 \\
\hline 47 & WI & 0.32919 & 0.26958 & 0.57054 & 0.41383 & 0.39893 & 0.4959 \\
\hline 48 & WY & 0.36495 & 0.29412 & 0.63453 & 0.36728 & 0.41391 & $0.5190^{\circ}$ \\
\hline
\end{tabular}


TABLE 6 (cont): HUMAN CAPITAL WITH VARIABLE WEIGHTS (HKVW, Logs)

\begin{tabular}{|c|c|c|c|c|c|c|}
\hline $\begin{array}{c}\text { US Mean } \\
\text { S.D. }\end{array}$ & $\begin{array}{l}0.325541 \\
0.041633\end{array}$ & $\begin{array}{l}0.27114 \\
0.02801\end{array}$ & $\begin{array}{l}0.58122 \\
0.04674\end{array}$ & $\begin{array}{l}0.42079 \\
0.03267\end{array}$ & $\begin{array}{l}0.40610 \\
0.02243\end{array}$ & $\begin{array}{l}0.51129 \\
0.02987\end{array}$ \\
\hline & 0.3393 & 0 & 0. & 0.4 & 0. & 0. \\
\hline South & 0.2795 & 0.2417 & 0.5 & 0.3970 & 0.3882 & 0.49007 \\
\hline Midwest & 0.3418 & 0.2760 & 0.5814 & 0.4225 & 0.4049 & 0.50685 \\
\hline est & 0.3632 & 0.3011 & 0.6379 & 0.4515 & 0.4274 & 0.52836 \\
\hline
\end{tabular}

Notes to Table 6:

(1) This table reports the logarithm of the computed stocks of human capital using variable welghts. See the text for a discussion of the construction of this measure.

(2) The four regions are defined by the Bureau of the Census. 
TABLE 7: HUMAN CAPITAL WITH FIXED WEIGHTS (HKFW, Logs)

\begin{tabular}{|c|c|c|c|c|c|c|c|}
\hline & & 940 & & 1960 & 1970 & & \\
\hline 1 & $A L$ & .21298 & 6123 & 0.33280 & 38992 & 0.46222 & 0.52592 \\
\hline 2 & $A Z$ & . 30599 & .37619 & 0.39725 & 0.46171 & 0.51640 & 0.55945 \\
\hline 3 & AR & 21839 & .24784 & 0.32652 & 0.37638 & 0.44742 & 50680 \\
\hline 4 & CA & 34428 & . 38395 & 42765 & 47027 & 0.53535 & 36850 \\
\hline 5 & $\mathrm{CO}$ & 32774 & 37189 & 43749 & 49064 & 0.55788 & .60120 \\
\hline 6 & CT & 29378 & 34660 & 39497 & 44626 & 0.52907 & 2 \\
\hline 7 & $D E$ & 6 & 0 & 1032 & 15 & 03 & 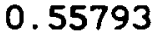 \\
\hline 8 & $F L$ & 9 & & 9 & 3 & & 0 \\
\hline 9 & ;A & 21793 & 14 & 9 & 1 & 5 & \\
\hline 0 & ID & & & 9 & & & \\
\hline 1 & IL & 4 & & 9 & 6 & & \\
\hline 2 & IN & 25 & 0. & 3 & 3 & & \\
\hline 3 & IA & 356 & 2 & & 5 & & \\
\hline 4 & KS & 31774 & 0.3 & 0.41 & 0.45621 & 9 & 43 \\
\hline 5 & KY & 23104 & 0.27085 & 0.32992 & 0.37441 & 0. & 0.3 \\
\hline 6 & LA & 21646 & 0.26664 & 0.33978 & 0.38629 & 0.47 & 0.31 \\
\hline 7 & ME & 29515 & 0.31949 & 0.36875 & 0.41889 & 0.48943 & 0.53974 \\
\hline 8 & MD & .27321 & 0.32998 & 0.38416 & 0.43488 & 0.52670 & 0.58078 \\
\hline 9 & MA & .32084 & 0.36341 & .40727 & 0.44123 & 0.5 & 0.59321 \\
\hline 0 & MI & 29603 & 0.33511 & 0.38146 & 0.42380 & 0.49529 & 0.54717 \\
\hline 1 & $\mathrm{MN}$ & 29759 & 0.33314 & 0.38786 & 0.44121 & 0.5 & 0.57187 \\
\hline 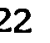 & MS & .20816 & 0.24425 & 0.32437 & 0.38265 & 0.4 & 0.49996 \\
\hline 3 & MO & .28039 & 0.32412 & .36420 & 0.42175 & 0.4 & 0.54007 \\
\hline 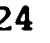 & MT & 8 & & & 0.4 & & 11 \\
\hline 5 & NE & & & 7 & 2 & & 0.5 \\
\hline 6 & NV & & & & 9 & & 22 \\
\hline 7 & $\mathrm{NH}$ & & & & 0 & & \\
\hline 8 & $\mathrm{NJ}$ & & & & 6 & & \\
\hline 9 & NM & c & & & & & \\
\hline 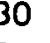 & NY & & & & & & \\
\hline 1 & $\mathrm{NC}$ & & & & & & \\
\hline 2 & ND & & & & & & \\
\hline 3 & $\mathrm{OH}$ & 2 & & 0. & 0 . & & 31 \\
\hline 4 & OK & 29744 & 0.3 & 0.40050 & $0.42^{\circ}$ & 0.5 & 73 \\
\hline 35 & OR & 0.32888 & 0.36879 & 0.41539 & 0.46398 & 0.53174 & 0.57487 \\
\hline 36 & PA & 0.27687 & 0.32927 & 0.36775 & 0.40119 & 0.48 & 0.53922 \\
\hline 37 & RI & 0.28232 & 0.33408 & 0.35789 & 0.373 & 0.4 & 0.53914 \\
\hline 38 & $\mathrm{SC}$ & 0.21364 & 0.25811 & 0.32054 & 0.36044 & 0.45134 & 0.51017 \\
\hline 39 & SD & 0.29138 & 0.32895 & 0.37315 & 0.37449 & 0.48784 & 0.52919 \\
\hline 40 & TN & 0.24053 & 0.28353 & 0.32807 & 0.37598 & 0.45790 & 0.51837 \\
\hline 41 & $T X$ & 0.28102 & 0.32250 & 0.37691 & 0.41146 & 0.49872 & 0.54670 \\
\hline 42 & UT & 0.35511 & 0.40910 & 0.45589 & 0.48678 & 0.55388 & 0.57835 \\
\hline 3 & VT & 0.29873 & 0.35431 & 0.38085 & 0.41461 & 0.50707 & 0.56407 \\
\hline 44 & $V A$ & 0.24865 & 0.31174 & 0.36213 & 0.41301 & 0.50807 & 0.56481 \\
\hline 5 & NA & 32807 & 0.38927 & 0.43141 & 0.45097 & 0.53743 & 0.58534 \\
\hline 46 & WV & 0.26431 & 0.29609 & 0.35312 & 0.40301 & 0.45540 & 0.50338 \\
\hline 7 & WI & 0.28466 & 0.32496 & 0.37476 & 0.41383 & 0.48994 & 0.53580 \\
\hline & WY & 0.32199 & 0.36114 & 0.41701 & 0.36728 & 0.51087 & 0.55754 \\
\hline
\end{tabular}


TABLE 7 (cont): HUMAN CAPITAL WITH FIXED WEIGHTS (HKFW, Logs)

$\begin{array}{cllllll}\text { US Mean } & 0.28559 & 0.32896 & 0.38001 & 0.42079 & 0.49913 & 0.54814 \\ \text { S.D. } & 0.036926 & 0.03900 & 0.03264 & 0.03267 & 0.02862 & 0.02550\end{array}$

$\begin{array}{lllllll}\text { Northeast } & 0.2958 & 0.3415 & 0.3809 & 0.4230 & 0.5074 & 0.56578 \\ \text { South } & 0.2460 & 0.2890 & 0.3511 & 0.3970 & 0.4761 & 0.52930 \\ \text { Midwest } & 0.2973 & 0.3340 & 0.3819 & 0.4225 & 0.4978 & 0.54532 \\ \text { West } & 0.3220 & 0.3712 & 0.4191 & 0.4515 & 0.5271 & 0.56420\end{array}$

Notes to Table 7:

(1) This table reports the logarithm of the computed stocks of human capital using fixed weights. See the text for a discussion of the construction of this measure.

(2) The four regions are defined by the Bureau of the Census. 
TABLE 8: AVERAGE YEARS OF SCHOOLING (logs)

\begin{tabular}{|c|c|c|c|c|c|c|c|}
\hline & & 1940 & 1950 & 1960 & 1970 & 1980 & \\
\hline 1 & AL & 1.9313 & 2.0754 & 2.2555 & 2.3725 & 2.4829 & 2.552 \\
\hline 2 & $A Z$ & 2.1679 & 2.2975 & 2.3752 & 2.4741 & 2.5504 & 2.578 \\
\hline 3 & AR & 1.9946 & 2.0821 & 2.2549 & 2.3730 & 2.4717 & 539 \\
\hline 4 & $\mathrm{CA}$ & 2.2927 & 2.3600 & 2.4352 & 2.4916 & 2.5655 & 2.574 \\
\hline 5 & $\mathrm{CO}$ & 2.2589 & 2.3367 & 2.4454 & 2.5181 & 2.5961 & 2.621 \\
\hline 6 & $\mathrm{CT}$ & 2.1936 & 2.2922 & 2. 3857 & 2.4514 & 2.5616 & 2.618 \\
\hline 7 & $\mathrm{DE}$ & 2.1794 & 2.2327 & 2.4001 & 2.4620 & 2.5448 & 2.592 \\
\hline 8 & FL & 2.1050 & 2.2179 & 2.3452 & 2.4230 & 2.5254 & 2.564 \\
\hline 9 & GA & 1.9393 & 2.0474 & 2.2360 & 2.3575 & 2.4901 & 2.561 \\
\hline 10 & ID & 2.2730 & 2. 3408 & 2.4222 & 2.4521 & 2.5570 & $2.57 \leqq$ \\
\hline 11 & IL & 2.2151 & 2.2944 & 2.3799 & 2.4405 & 2.5390 & 2.584 \\
\hline 12 & IN & 2.2289 & 2. 3059 & 2. 3879 & 2.4367 & 2.5168 & 2.559 \\
\hline 13 & IA & 2.2554 & 2. 3178 & 2.3961 & 2.4723 & 2.5415 & 2.578 \\
\hline 4 & KS & 2.2647 & 2.3359 & 2.4223 & 2.4867 & 2.5615 & 2.5 \\
\hline 15 & KY & 2.0327 & 2.1 & 2.2640 & 2.3599 & 2 & 2.5 \\
\hline 16 & LA & 1.8991 & 2.0 & 2.2394 & 2.3519 & 2 & 2.5 \\
\hline 17 & ME & 2.2280 & 2.2718 & 2.3698 & 2.4211 & 2 & 2.57 \\
\hline 18 & MD & 2.1103 & 2.2 & 2.3 & 2.4 & 5 & 2.6 \\
\hline 19 & MA & 2.24 & 2.32 & 2.4 & 2.4 & 5 & 2.61 \\
\hline 20 & MI & 2.21 & 2.2 & 2.3 & 2.4 & 2 & $2.5 \varepsilon$ \\
\hline 21 & MN & 2.22 & 2.2 & 2. 3902 & 2.4 & 2 & 2.6 \\
\hline 22 & MS & 1.9 & 2. & 2.2304 & 35 & & 2.52 \\
\hline 23 & MO & 2.1788 & 2.2622 & 2.3479 & 2.4394 & 2.5201 & 2.571 \\
\hline 24 & MT & 2.2429 & 2.3180 & 2.4085 & 2.4791 & 2.5727 & 2.5867 \\
\hline 25 & NE & 2.2550 & 2.3234 & 2.4150 & 2. 4597 & 2.5624 & 2.579 \\
\hline 26 & NV & 2.2670 & 2.3323 & 2.4277 & 2.4650 & 2.5405 & 2.553 \\
\hline 27 & NH & 2.2288 & 2.2941 & 2. 3664 & 2.4660 & 2.5545 & 2.604 \\
\hline 28 & NJ & 2.1788 & 2.2667 & 2.3747 & 2.4334 & 2.5464 & 2.598 \\
\hline 29 & NM & 2.0695 & 2.2490 & 2.3929 & 2.4669 & 2.5414 & 2.579 \\
\hline 30 & NY & 2.2044 & 2.2846 & 2.3860 & 2.4546 & 2.5513 & 2.5937 \\
\hline 31 & $\mathrm{NC}$ & 1.9986 & 2.0878 & 2.2397 & 2.3128 & 2.4730 & 2.552 \\
\hline 32 & ND & 2.1730 & 2.2337 & 2.3393 & 2.4345 & 2.5270 & 2.578 \\
\hline 33 & $\mathrm{OH}$ & 2.2278 & 2.2974 & 2. 3882 & 2.4371 & 2.5289 & 2.5735 \\
\hline 34 & OK & 2.1875 & 2.2886 & 2. 3904 & 2.4455 & 2.5378 & 2.5732 \\
\hline 35 & OR & 2.2888 & 2. 3490 & 2.4324 & 2.4925 & 2.5770 & 2.598 \\
\hline 36 & PA & 2.1566 & 2.2683 & 2.3602 & 2.4196 & 2.5313 & 2.579 \\
\hline 37 & RI & 2.1517 & 2.2631 & 2.3321 & 2. 3664 & 2.4901 & $2.557^{\prime}$ \\
\hline 38 & SC & 1.9052 & 2.0481 & 2.2147 & 2. 3086 & 2.4624 & 2.538 \\
\hline 39 & SD & 2.2077 & 2.2778 & 2.3692 & 2. 3894 & 2. 5281 & 2.560 \\
\hline 40 & TN & 2.0405 & 2.1550 & 2.2574 & 2.3538 & 2.4770 & 2.5436 \\
\hline 41 & $\mathrm{TX}$ & 2.1251 & 2.2103 & 2.3292 & 2.3984 & 2.5151 & 2.554 \\
\hline 42 & UT & 2.3236 & 2.3981 & 2.4867 & 2.5217 & 2.5984 & 2.602 \\
\hline 43 & VT & 2.2290 & 2.3206 & 2.3779 & 2.4256 & 2.5507 & 2.596 \\
\hline 44 & VA & 2.0223 & 2.1738 & 2.2995 & 2.3949 & 2.5289 & 2.58 \\
\hline 45 & WA & 2.2834 & 2.3762 & 2.4509 & 2.4916 & 2.5819 & 2.609 \\
\hline 46 & WV & 2.1027 & 2.1952 & 2.3100 & 2.4034 & 2.4900 & 2.540 \\
\hline 47 & WI & 2.1924 & 2.2766 & 2.3727 & 2.4347 & 2.5365 & 2.573 \\
\hline 48 & WY & 2.2611 & 2.3291 & 2.4291 & 2.3933 & 2.5583 & 2.5 \\
\hline
\end{tabular}


TABLE 8 (cont): AVERAGE YEARS OF SCHOOLING (logs)

\begin{tabular}{|c|c|c|c|c|c|c|}
\hline $\begin{array}{c}\text { US Mean } \\
\text { S.D. }\end{array}$ & $\begin{array}{l}2.1600 \\
0.1134\end{array}$ & $\begin{array}{l}2.2510 \\
0.0950\end{array}$ & $\begin{array}{l}2.3600 \\
0.0663\end{array}$ & $\begin{array}{l}2.4288 \\
0.0504\end{array}$ & $\begin{array}{l}2.5332 \\
0.0350\end{array}$ & $\begin{array}{l}2.5762 \\
0.0233\end{array}$ \\
\hline Northeast & 2.2018 & 2.2878 & 2.3738 & 2.4330 & 2.5429 & 2. 59297 \\
\hline South & 2.0309 & 2.1413 & 2.2888 & 2.3810 & 2.4997 & 2.55696 \\
\hline Midwest & 2.2199 & 2.2925 & 2.3826 & 2.4451 & 2.5396 & 2. 57806 \\
\hline West & 2.2480 & 2. 3351 & 2.4278 & 2.4769 & 2. 5671 & 2. 58858 \\
\hline
\end{tabular}

Notes to Table 8:

(1) This table reports the logarithm of the average years of schooling. See the text for a discussion of the construction of this measure.

(2) The four regions are defined by the Bureau of the Census. 
TABLE 9

CONTEMPORANEOUS CORRELATIONS OF THE VARIOUS MEASURES OF HUMAN CAPITAL

\begin{tabular}{|c|c|c|c|c|}
\hline & HY & 1940 & & School \\
\hline Human Capital & $\begin{array}{l}\text { HK } \\
1\end{array}$ & $\begin{array}{l}\text { VW } \\
0.62\end{array}$ & $\begin{array}{l}F W \\
0.59\end{array}$ & $\begin{array}{l}\text { School } \\
0.62\end{array}$ \\
\hline Variable Weights & & 1 & 0.99 & 0.99 \\
\hline Fixed Weights & & & 1 & 0.97 \\
\hline Schooling & & & & 1 \\
\hline & & 1950 & & \\
\hline & HK & VW & $\mathrm{FW}$ & \\
\hline $\begin{array}{l}\text { Human Capital } \\
\text { Variable Weights }\end{array}$ & & 0.47 & 0.48 & $\begin{array}{l}0.45 \\
0.97\end{array}$ \\
\hline $\begin{array}{l}\text { Varlable Weights } \\
\text { Fixed Welghts }\end{array}$ & & 1 & 0.99 & $\begin{array}{l}0.97 \\
0.96\end{array}$ \\
\hline Schooling & & & & 1 \\
\hline & & 1960 & & \\
\hline & HK & VW & FW & School \\
\hline $\begin{array}{l}\text { Human Capital } \\
\text { Variable Weights }\end{array}$ & 1 & 0.42 & 0.40 & 0.32 \\
\hline $\begin{array}{l}\text { Variable Weights } \\
\text { Fixed Weights }\end{array}$ & & 1 & 0.99 & 0.94 \\
\hline $\begin{array}{l}\text { Fixed Weights } \\
\text { Schooling }\end{array}$ & & & 1 & 0.96 \\
\hline & & 1970 & & 1 \\
\hline & HK & VW & FW & School \\
\hline Human Capital & 1 & 0.23 & 0.23 & 0.17 \\
\hline Variable Weights & & 1 & 1 & 0.94 \\
\hline Fixed Weights & & & 1 & 0.94 \\
\hline Schooling & & & & 1 \\
\hline & & 1980 & & \\
\hline & HK & VW & FW & School \\
\hline Human Capital & 1 & 0.30 & 0.29 & 0.19 \\
\hline Variable Weights & & 1 & 1 & 0.97 \\
\hline $\begin{array}{l}\text { Fixed Weights } \\
\text { Schooling }\end{array}$ & & & 1 & 0.97 \\
\hline & & 1990 & & \\
\hline & HK & VW & FW & School \\
\hline Human Capital & 1 & 0.26 & 0.25 & 0.26 \\
\hline Variable Weights & & 1 & 0.99 & 0.96 \\
\hline Fixed Weights & & & 1 & 0.96 \\
\hline Schooling & & & & 1 \\
\hline
\end{tabular}


TABLE 10

ESTIMATES OF THE ELASTICITY OF SUBSTITUTION BETWEEN WORKERS WITH AND WITHOUT SCHOOLING

\begin{tabular}{|c|c|c|c|}
\hline Census & $\begin{array}{l}\text { Coefficlent on } \\
\text { relative supplies } \\
\text { (std error) }\end{array}$ & $\begin{array}{l}\text { Implied elasticity } \\
\text { of substitution }\end{array}$ & [std error of regr] \\
\hline$w(0)$ & $=$ within-state avg & akly earnings for th & with school $<5$ \\
\hline 1940 & $\begin{array}{c}-0.159 \\
(0.019)\end{array}$ & 6.30 & $\begin{array}{l}.61 \\
{[.099]}\end{array}$ \\
\hline 1950 & $\begin{array}{l}-0.146 \\
(0.022)\end{array}$ & 6.83 & {$\left[\begin{array}{l}.45 \\
{[.115]}\end{array}\right.$} \\
\hline 1960 & $\begin{array}{l}-0.109 \\
(0.022)\end{array}$ & 9.14 & {$\left[\begin{array}{l}.34 \\
{[.128]}\end{array}\right.$} \\
\hline 1970 & $\begin{array}{c}0.002 \\
(0.057)\end{array}$ & $\infty$ & $\begin{array}{l}-.02 \\
{[.296]}\end{array}$ \\
\hline 1980 & $\begin{array}{l}-0.022 \\
(0.041)\end{array}$ & 45.05 & $\begin{array}{l}-.02 \\
{[.222]}\end{array}$ \\
\hline 1990 & $\begin{array}{l}-0.040 \\
(0.045)\end{array}$ & 24.75 & $\begin{array}{l}-.00 \\
{[.208]}\end{array}$ \\
\hline restricted & $\begin{array}{l}-0.121 \\
(0.011)\end{array}$ & 8.24 & \\
\hline
\end{tabular}

In $w(0)=$ Mincer regression constant

$\begin{array}{lcll}1940 & 0.121 & \infty & .16 \\ & (0.038) & & {[.205]} \\ 1950 & 0.055 & \infty & .02 \\ & (0.037) & & {[.192]} \\ 1960 & -0.012 & 81.30 & -.02 \\ & (0.035) & & {[.207]} \\ 1970 & 0.003 & \infty & -.02 \\ & (0.043) & & {[.243]} \\ 1980 & -0.011 & 90.09 & -.02 \\ & (0.029) & & {[.167]} \\ 1990 & -0.037 & 27.25 & -.00 \\ & (0.037) & & {[.185]} \\ \text { restricted } & 0.014 & \infty & \end{array}$


Notes

(1) Dependent variable is $\ln (w(0) / w(\sim 0))$, where $w(\sim 0)$ is the average weekly earnings of those with 5 or more years of schooling (and who are in our earnings sample) for the top panel and $w(\sim 0)$ is average weekly earnings of all workers in our wage sample for the bottom panel.

(2) The independent variable is $\ln [(\eta(0)+\eta(1)) /(1-\eta(0)-\eta(1))]$. Constants are also included in the regressions.

(3) In the top panel only, NE, SD, UT, and WY are excluded in 1970, VT in 1980, ND and VT in 1990 because, for these states, no person in our wage sample has fewer than 5 years of schooling. NE, ND, SD, UT, VT, and WY are excluded in the top panel's restricted regression.

(4) Cross-sectional regressions are estimated by OLS. Pooled regressions are estimated with an iterative weighted least squares procedure. 
Barro, Robert J. "Economic Growth in a Cross-Section of Countries." Quarterly Journal of Economics. May 1991.

Barro, Robert J. and Jong Wa Lee. "International Comparisons of Educational Attainment." NBER Working Paper \#4349, May 1993.

Barro, Robert J. and Jong Wa Lee. "Winner and Losers in Economic Growth." NBER Working Paper \#4341, May 1993.

Barro, Robert J., N.G. Mankiw and Xavier Sala-1-Martín. "Capital Mobllity in Neoclassical Models of Growth." Working paper, Harvard University, 1992.

Barro, Robert J. and Xavier Sala-i-Martin. "Convergence." Journal of Political Economy. 100(2), Apr1l 1992.

Becker, Gary S. "Human Capital." Chicago: University of Chicago Press, 1975.

Ben-Porath, Yoram. "The Production of Human Capital and the Life Cycle of Earnings." Journal of Political Economy. 75, 1967: 352-65.

Card, David. and Alan B. Krueger. "Does Schooling Quality Matter? Returns to Education and the Characteristics of Public Schools in the United States." Journal of Political Economy. 100(1), February 1992.

Friedman, Milton. A Theory of the consumption Function. Princeton, NJ: Princeton University Press, 1957.

Heckman, James. "A Life-Cycle Model of Earnings, Learning and Consumption." Journal of Political Economy. 1976.

Juhn, Murphy and Plerce. Journal of Political Economy. 1993.

Kiriakou. "" New York University PhD dissertation, 1991.

Lucas, Robert E., Jr. "On the Mechanics of Economic Development." Journal of Monetary Economics. 1988.

Mankiw, N.G., David Romer and David Well. "A Contribution to the Empirics of Economic Growth." 1992.

Mulligan, Casey B. and Xavier Sala-i-Martín. "Transitional Dynamics in Two Sector Models of Endogenous Growth." Quarterly Journal of Economics. August 1993.

National Center for Education Statistics. Digest of Education statistics. Washington: $\subset$, various issues. 
United States Bureau of the Census. Census of Population, various years. Washington: U.S. Department of Commerce.

United States Department of Commerce, Bureau of Economic Analysis. Personal Income by State: Estimates for 1929-1982, and a statement of Sources and Methods. Washington: Government Printing office, 1984.

United States Department of Commerce, Bureau of Economic Analysis. Regional Economic Information system. Washington: B.E.A. Regional Economic Measurement Division, 1992.

United States Department of Health, Education and Welfare, Office of Education. Biennial Survey of Education in the onited states. Washington: @, various issues.

Willis, Robert J. "Wage Determinants: A Survey and Reinterpretation of Human Capital Earnings Functions." in Orley Ashenfelter and Richard Layard, eds. Handbook of Labor Economics. Volume 1. New York: North-Holland, 1986. 
Figure 1

\section{Educational Attainment: 1940-90 U.S. Civilian Labor Force, ages 25-65}
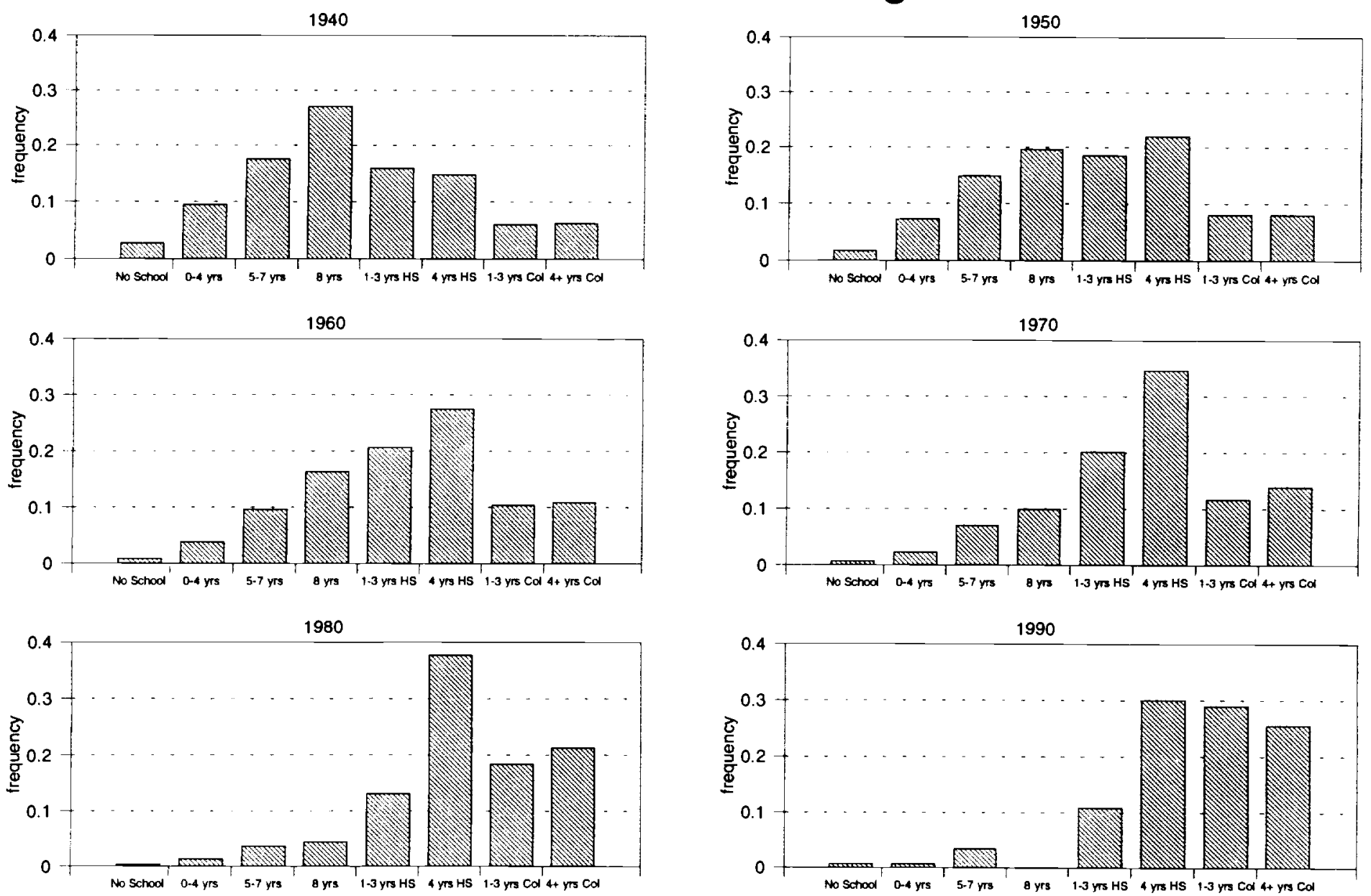
Figure 2: Human Capital for Four Census Regions, 1940-1990

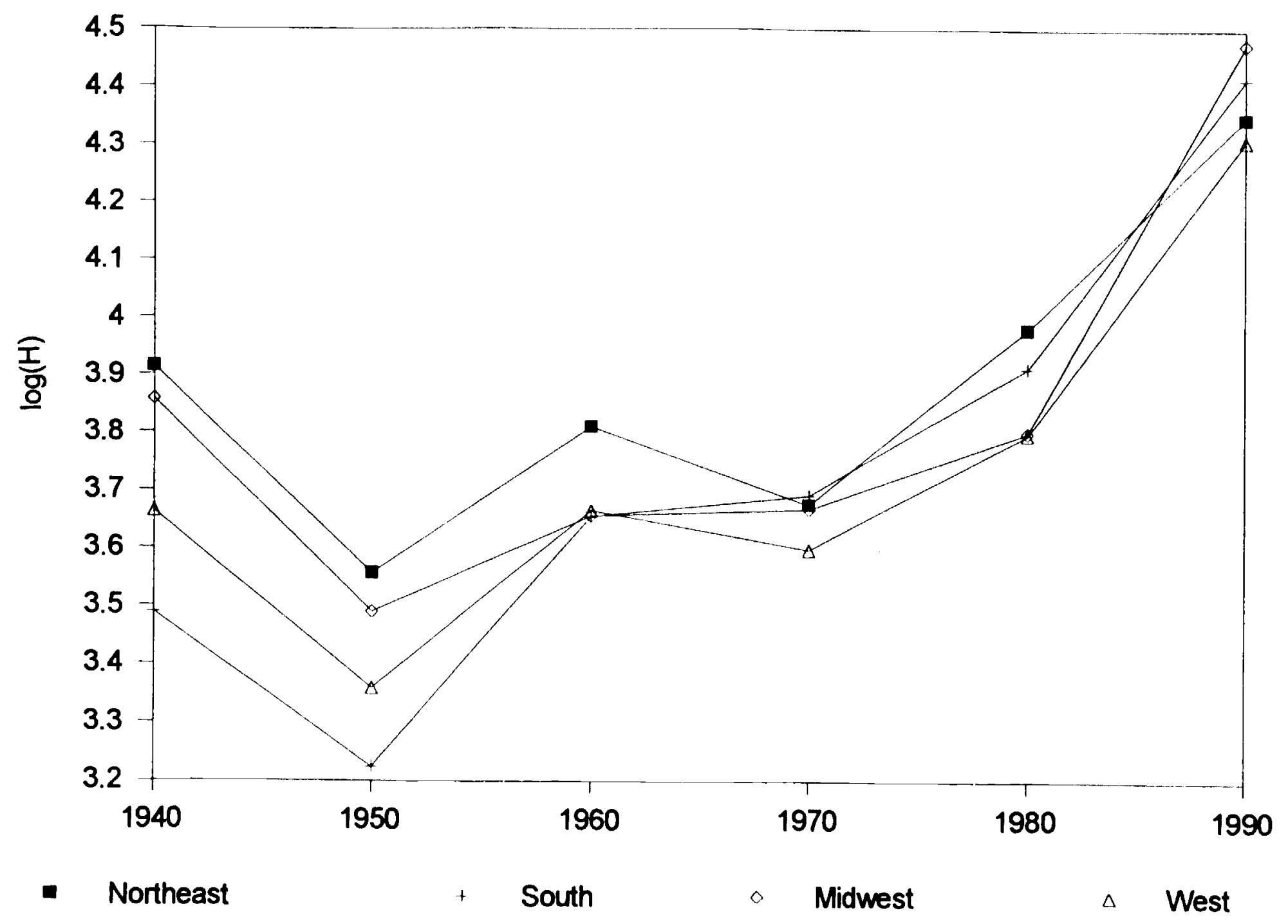


Figure 3: Human Capital and w(0) across 48 States, 1990

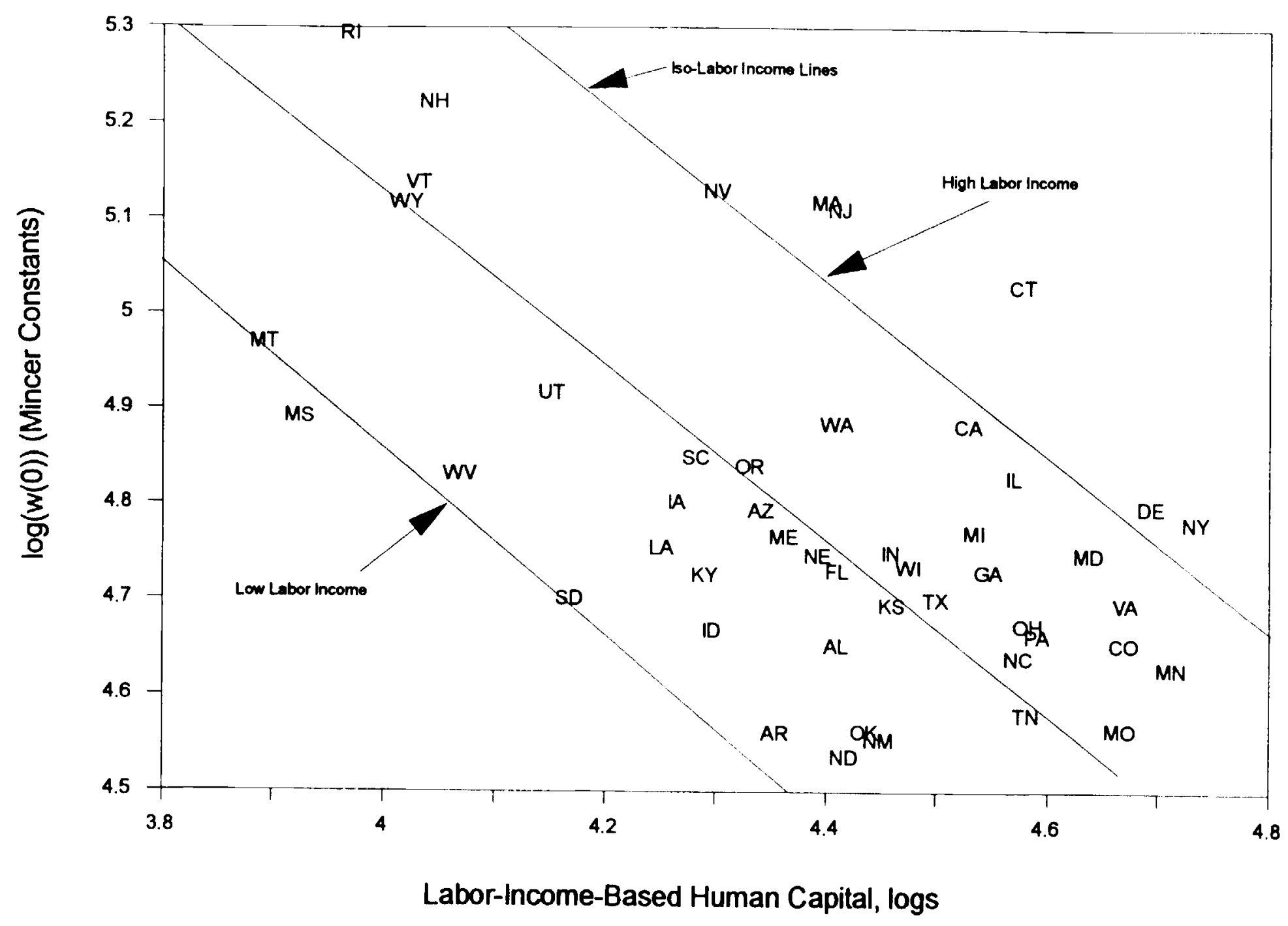


Figure 4: Human Capital and w(0) across 48 States, 1940

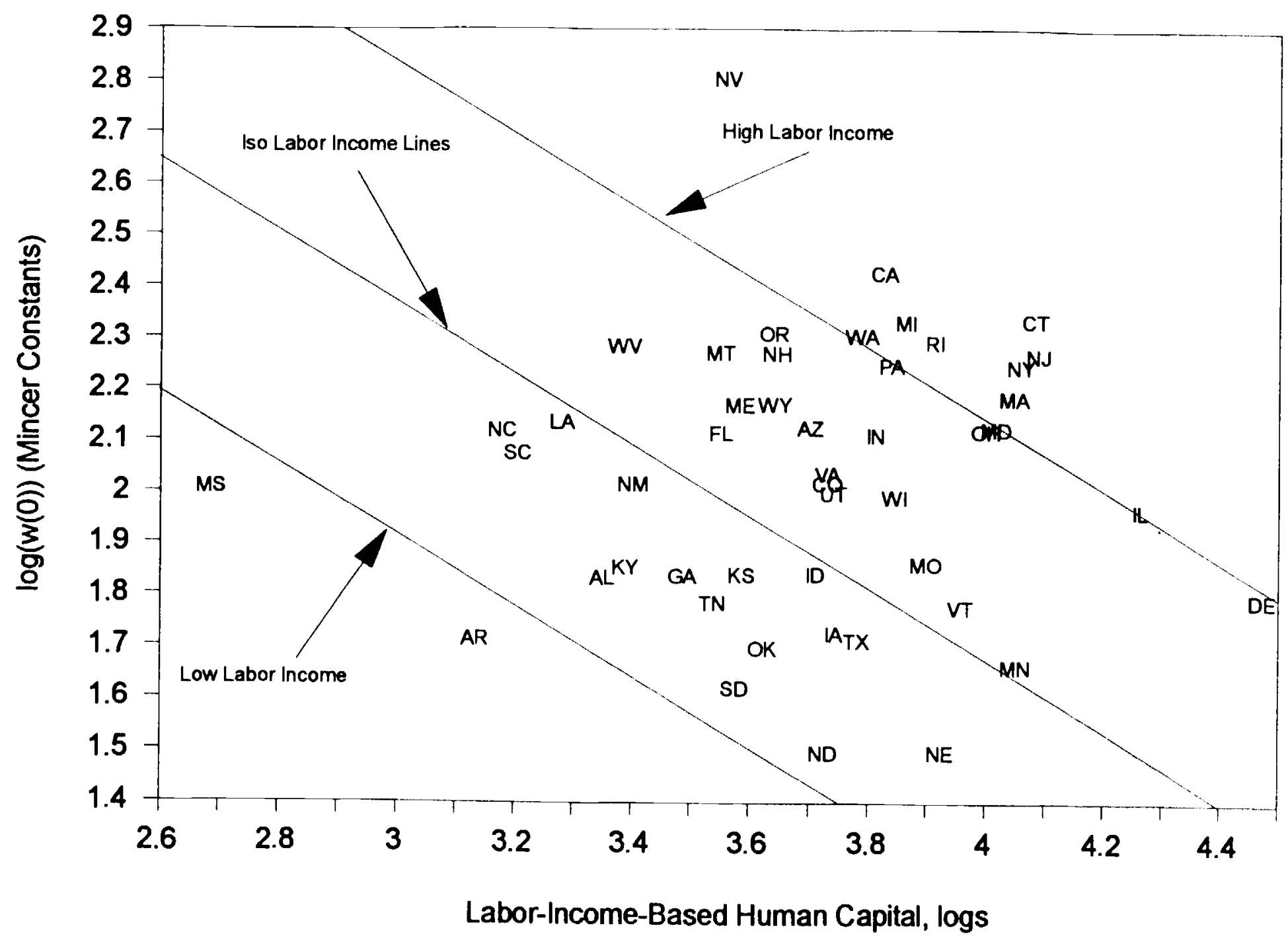


Figure 5:

Labor Income Per Capita for Four Census Regions, 1940-1990

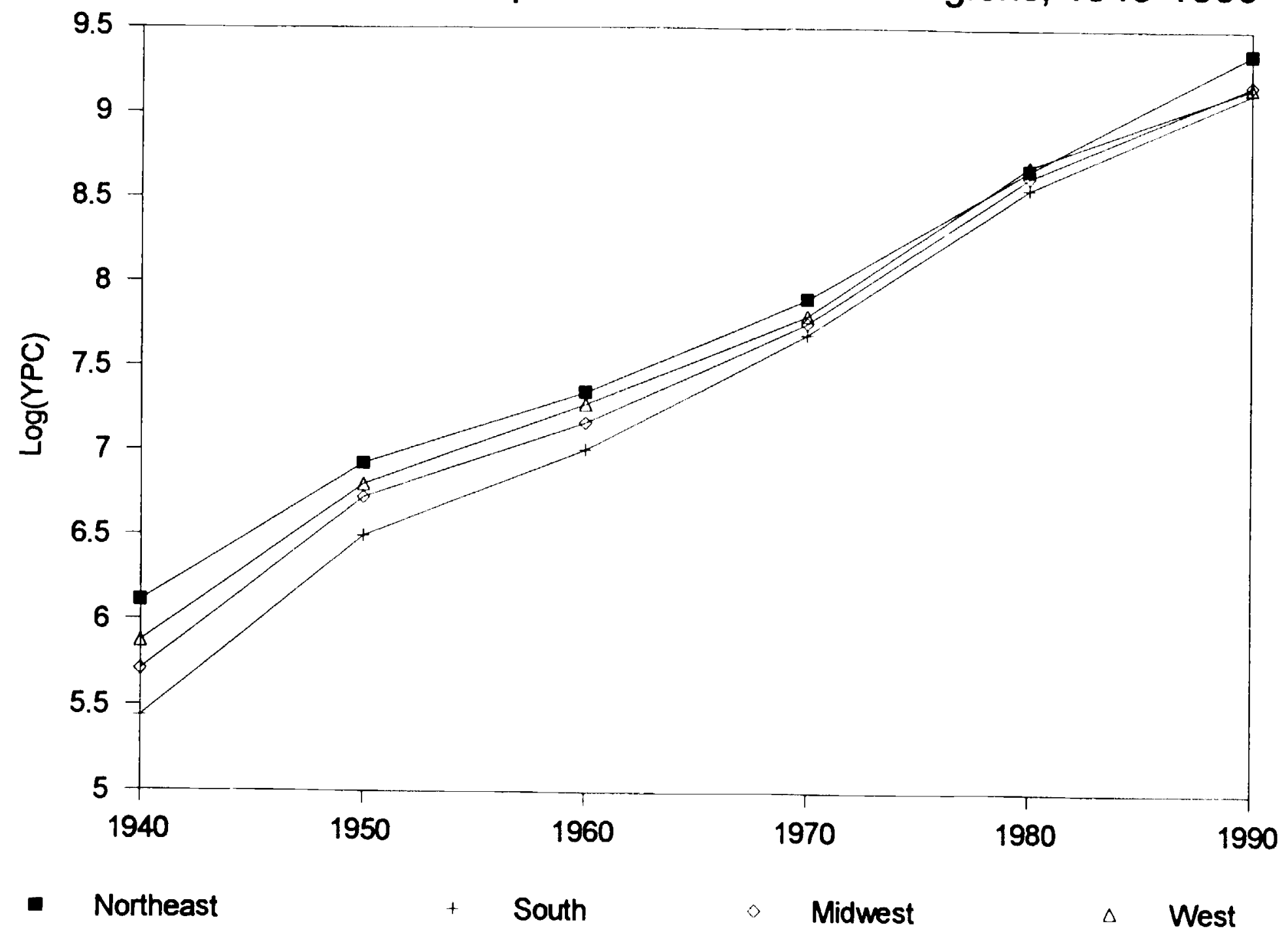


Figure 6: $w(0)$ for four Census Regions, 1940-1990

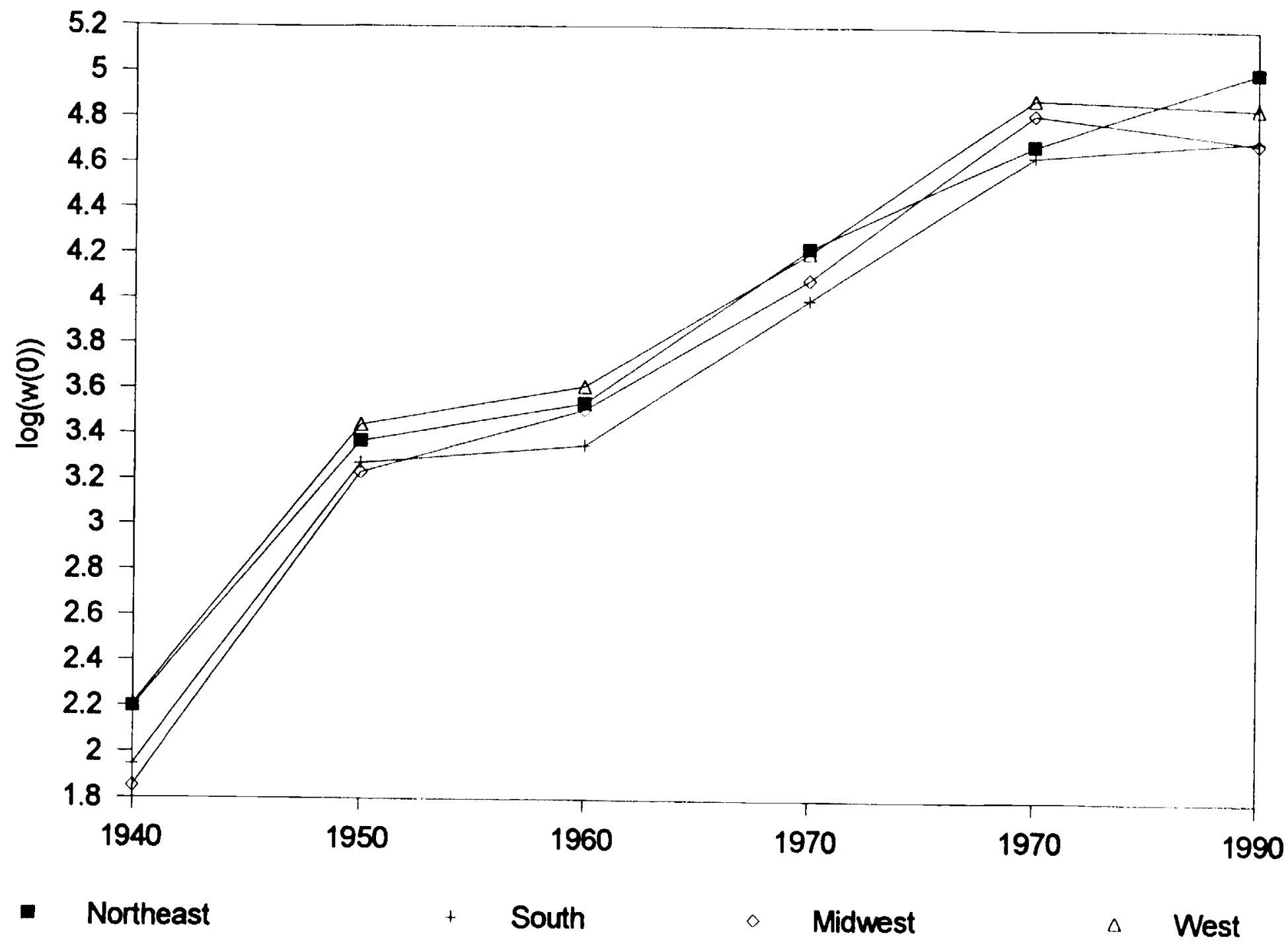




\section{Figure 7}

Avg Wkly Earnings vs Schooling, 1940-90

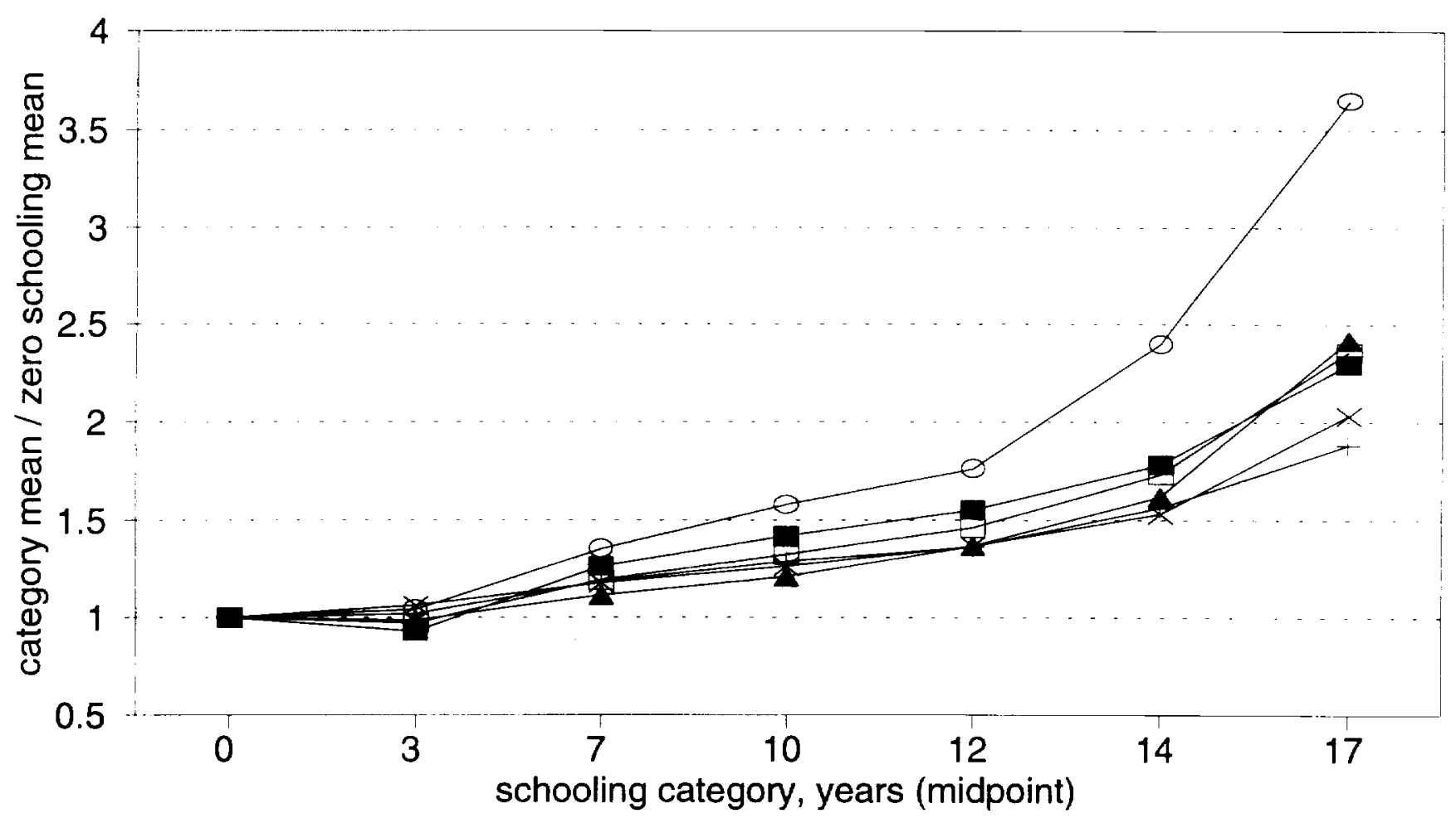

$-40+50 \odot 60 \square 70 \times 80 \_90$ 
Figure 8:

Different Measures of Human Capital, U.S. avgs. 1940-1990

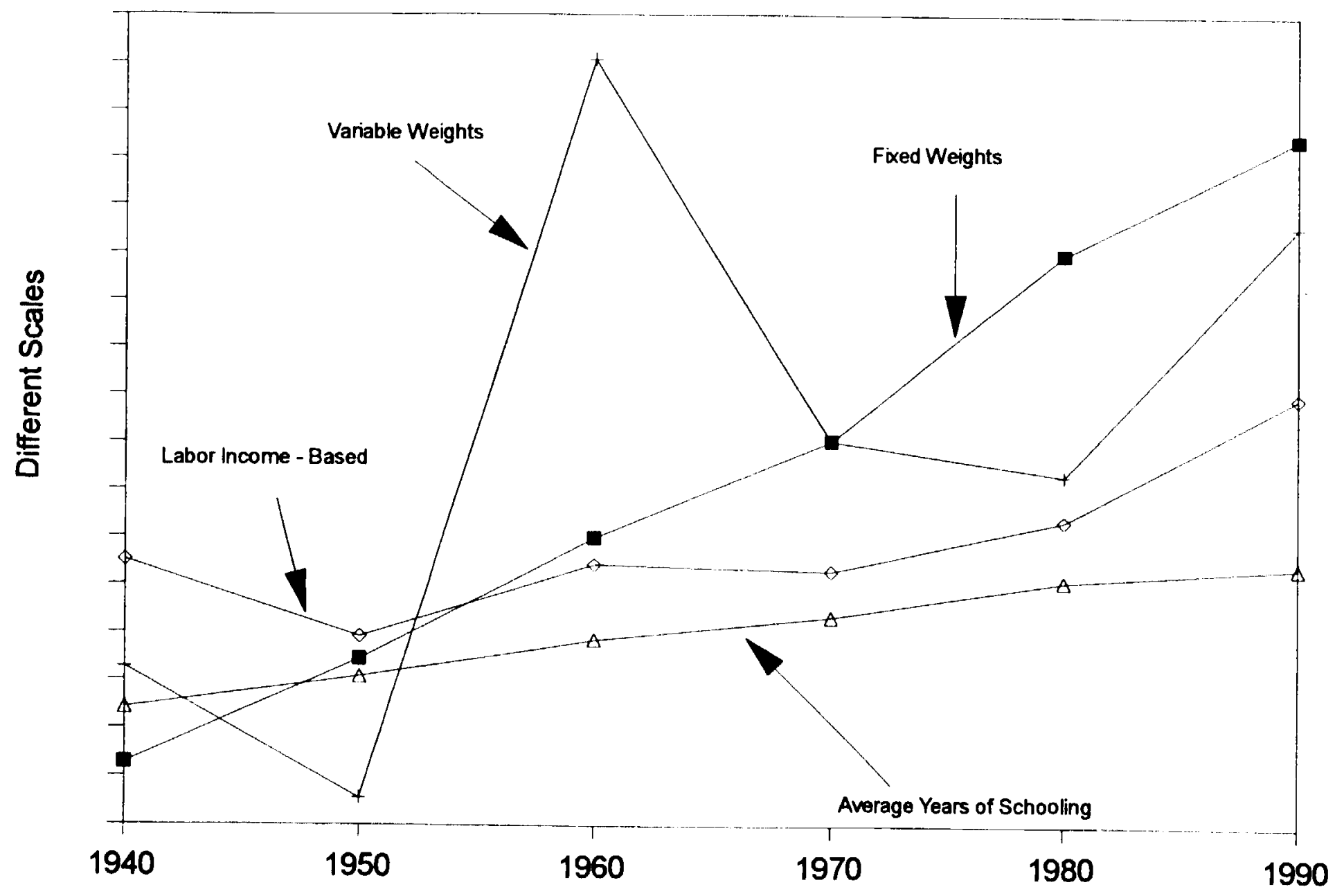




\section{Figure 9}

Labor-Income-Based and Variable Weight Measures, 1990

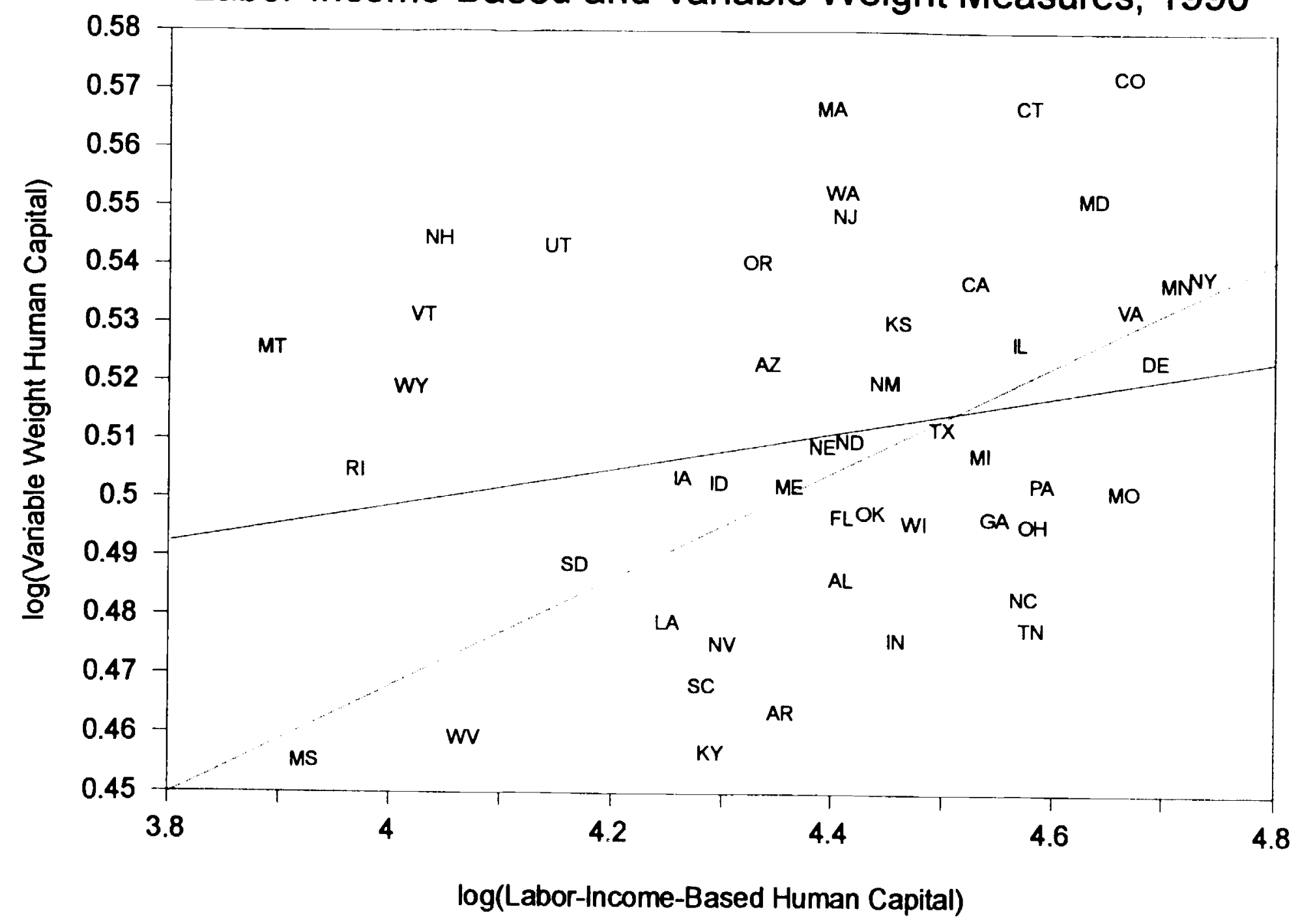


Figure 10:

Human Capital vs. Average Schooling, 1990

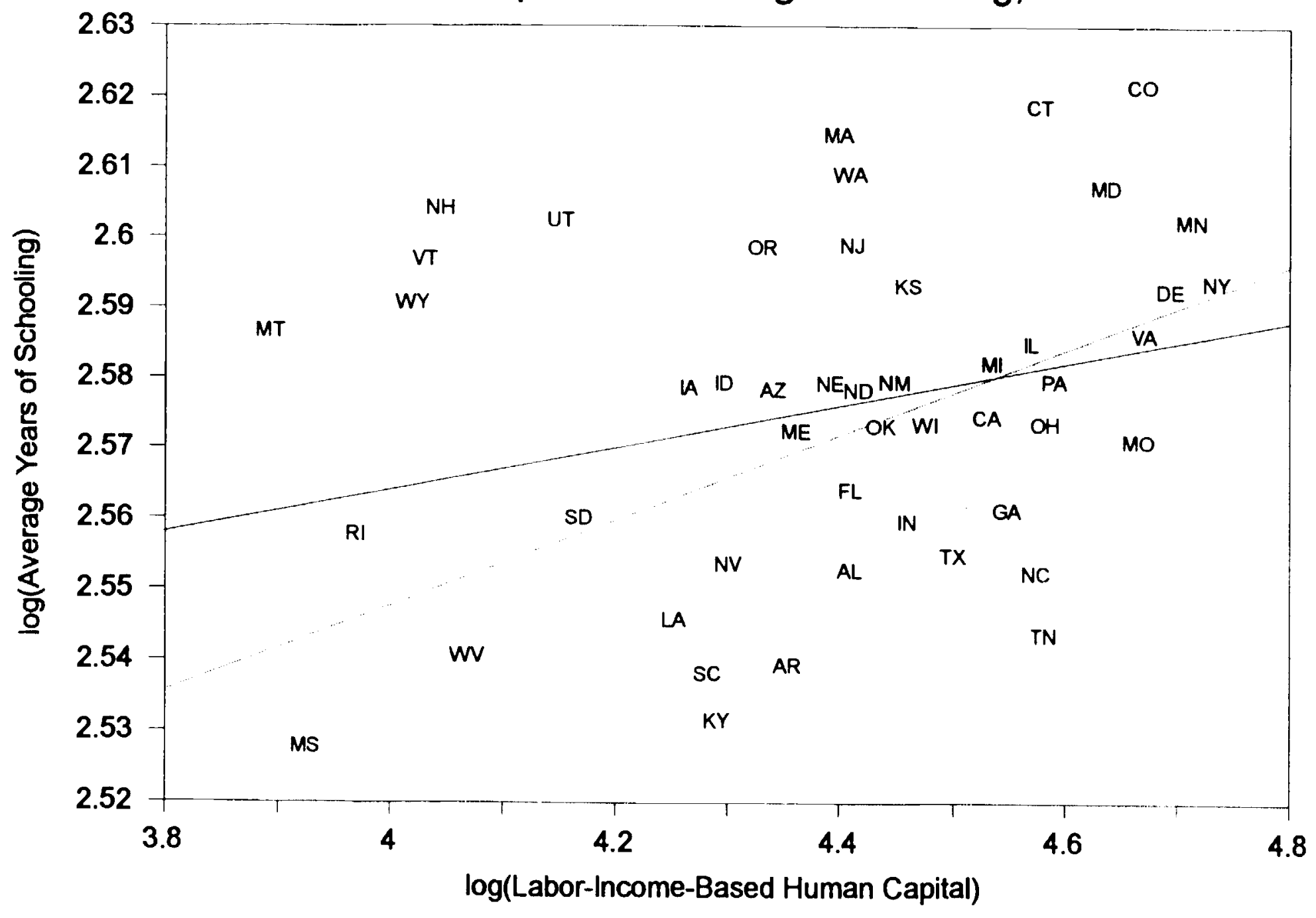

